\title{
Resilience of dynamic coastal benthic ecosystems in response to large-scale finfish farming
}

\author{
Nigel Keeley ${ }^{1, *}$, Thomas Valdemarsen ${ }^{2,3}$, Skye Woodcock ${ }^{1}$, Marianne Holmer ${ }^{2}$, \\ Vivian Husa ${ }^{1}$, Raymond Bannister ${ }^{1}$ \\ ${ }^{1}$ Institute of Marine Research, 9007 Tromsø, Norway \\ ${ }^{2}$ University of Southern Denmark, 5230 Odense, Denmark \\ ${ }^{3}$ Danish Environmental Protection Agency, 2100 Copenhagen, Denmark
}

\begin{abstract}
Global expansion of salmon aquaculture is contingent upon finding new, large-capacity farming locations that are, increasingly, situated in dispersive environments with atypical ecological characteristics. The capacity of such sites to assimilate organic waste and the type and spatial extent of effects remain poorly understood. This study couples intensive spatial and temporal measurements of waste outputs with measurements of benthic ecological diversity and sediment biogeochemistry at a shallow dispersive site on the central west coast of Norway. Despite minimal visual changes to the seabed, pronounced biological effects were evident out to 600-1000 m away from the farm. Greatly enhanced faunal and microbial activity was tightly coupled with strong sediment respiratory responses in the form of oxygen uptake and ammonia efflux. The benthic response was highly dynamic, with rapid and prolific colonization by opportunistic fauna, followed by substantive recovery during the subsequent 7 mo fallowing period. The fate and pathways of farm waste through the environment was compartmentalized by converting measured parameters into equivalent carbon fluxes. During early production, approximately $30-40 \%$ of the waste was accounted for by the measured benthic processes, attributed to faunal respiratory activity and the physical properties including sediment type. Later in the production cycle, a sediment burial event was observed down-current from the farm. The remaining $60-70 \%$ of organic waste was assumed to be either assimilated in the water column, consumed by large, unquantified benthic fauna, or exported and dispersed. Shallow, dispersive sites therefore appear relatively resilient to acute near-field enrichment, but are also more likely to result in accumulative, far-field effects.
\end{abstract}

KEY WORDS: Assimilation capacity · Respiration · Atlantic salmon · Salmo salar · Organic waste · Norway

\section{INTRODUCTION}

Sea-cage rearing of Atlantic salmon Salmo salar is a large, lucrative and rapidly expanding sector of the aquaculture industry. In 2014, global production exceeded 2.3 million $\mathrm{t}$ (www.fao.org/fishery/species/ 2929/en), and in 2016, Atlantic salmon farming contributed \$US 7 billion to the Norwegian economy alone (https://www.ssb.no/en/fiskeoppdrett). Future expansion is mostly contingent upon finding new, highly productive farming locations. A critical factor

\footnotetext{
*Corresponding author: nkeeley@hi.no
}

in site selection concerns the ability of the receiving environment to cope with the substantial quantities of organic waste produced (Gowen \& Bradbury 1987, MPI 2013). The common perception is that this can be achieved by shifting farms to more exposed, dynamic and dispersive coastal ecosystems that are generally better equipped to cope with the waste (Ibrekk et al. 1993, Keeley et al. 2013a, Valdemarsen et al. 2015). However, the mechanisms by which these systems cope remain poorly understood.

(C) The authors 2019. Open Access under Creative Commons by Attribution Licence. Use, distribution and reproduction are unrestricted. Authors and original publication must be credited. 
With greater resilience comes greater capacity, and hence dispersive sites will inevitably be associated with very high production levels and proportionally high levels of waste discharge. For example, the farm described in this manuscript used ca. $9000 \mathrm{t}$ of fish feed in 1 production cycle (ca. 12 mo), and at peak standing biomass (just prior to harvest), approximately $35 \mathrm{t}$ of pelletized feed were used each day. Of this, approximately $30 \%$ is discharged as feces (Brooks \& Mahnken 2003), and between 22 and $35 \%$ of the carbon is discharged in particulate form (Merican \& Phillips 1985, Wang et al. 2012), which sinks to the seafloor and interacts with the benthic environment. In a non-dispersive environment, high deposition of organic waste often exceeds the benthic assimilation capacity, causing localized anoxia and resulting in benthic malfunctioning with highly degraded sediments devoid of macrofauna (Gowen \& Bradbury 1987, Brooks \& Mahnken 2003, Valdemarsen et al. 2012). At physically dynamic sites, water currents and sediment resuspension effectively disperse organic waste over larger areas, resulting in a more diffuse impact footprint (Broch et al. 2017), and sediments beneath the cages can even appear visually unimpacted (N. Keeley pers. obs.). Inevitably, dispersive environments will also have limited assimilative capacity, which remains poorly defined.

The fact that greater dispersal leads to a larger benthic footprint is an important environmental effects characteristic of dispersive, assimilative sites. While non-dispersive sites typically have noticeable effects out to ca. 150 m (Brooks et al. 2002, MPI 2013), footprints at dispersive sites have been observed as far as 300-500 $\mathrm{m}$ from the farm (Keeley et al. $2013 a, b)$. There is also greater potential for effects further afield, as an unknown portion of the waste is likely being exported from the local area through resuspension (Chamberlain \& Stucchi 2007, Keeley et al. 2013b, Broch et al. 2017). This leads to a philosophical debate about the opposing concepts of 'contain and contaminate' (as is the case at shallow, lowflow sites) versus the commonly touted solution to pollution of 'dilute and disperse'. The former is associated with excessive and often undesirable levels of enrichment (Brooks et al. 2002), yet the impact is usually constrained to a relatively small and predictable area of seabed (Mayor \& Solan 2011, Cromey et al. 2012), whereas the latter has less definitive spatial boundaries and can only be 'sustained' if the waste material can be assimilated at the rate at which it is being delivered without impacting living or nonliving resources (Goldberg 1981). More specifically, in a fish-farming context, assimilative capacity has been defined as the rate of deposition of organic wastes that maximizes total organic carbon degradation rates while preventing adverse geochemical conditions (Bravo \& Grant 2018). Implicit in these definitions are several important questions, including: What is the maximum rate of degradation? How is the waste assimilated and mineralized in the surrounding environment? But also, more broadly: Are any ecologically significant organisms being affected? If so, on what spatial scale? The significance of these questions is also amplified when the activity is occurring in the vicinity of commercially important wild fisheries (e.g. abalone and lobster; Walters 2007, Lisson 2014).

Knowledge gaps related to how fish farm waste is assimilated and mineralized in dispersive locations can also lead to confusion over what constitutes an optimal site. The physical properties of depth and current speed are used synonymously as desirable attributes for dispersion (Ibrekk et al. 1993, Hargrave 2002, Belle \& Nash 2008), and although both promote dispersion, they can occur independently and induce quite different effects. Higher current speeds clearly transport waste greater horizontal distances, thus creating a broader footprint (Frid \& Mercer 1989, Mayor \& Solan 2011), but particles can also resuspend and undergo secondary transportation due to elevated critical shear stresses (Cromey et al. 2002, Law et al. 2016). As a result, organic accumulation can be minimal (Keeley et al. 2013a, Broch et al. 2017). Additionally, strong currents ensure good oxygen supply to the seabed, which fuels benthic respiratory processes (Findlay \& Watling 1997), whereas water depth increases dispersion due to the increased transit time of the particles. In the presence of moderate currents, waste can be dispersed over relatively large distances (Kutti et al. 2007a), but in the absence of horizontal dispersion, waste dispersal can also be minimal (Valdemarsen et al. 2012). Although deep locations (i.e. fjords) can have strong currents in surface waters, mid- and near-bottom current speeds are typically very low, resulting in minimal resuspension (Bannister et al. 2016). Metabolic rates and particle breakdown may also be impaired due to reduced water temperatures at depth (Brown et al. 2004), thereby contributing to the accumulation of biodeposits. Differences in metabolic capacities between deep and shallow sites may also be exacerbated by contrasting sediment grain sizes, which tend to be coarser in high current settings, as this physical property can influence decomposition rates and thus impact potential (Papageorgiou et al. 2010, Martinez-Garcia et al. 2015). 
A useful first step in understanding the assimilative capacity of shallow dispersive sites is therefore comprehending how much waste is being metabolized locally in the 'near-field' (<1000 m away), and accordingly, how much is being exported and potentially available to induce 'far-field' effects. Here we present a detailed case study based around a large, high-capacity farm situated in a dispersive environment in a semi-exposed coastal ecosystem on the central west coast of Norway. The flux of waste from the farm was measured in conjunction with the benthic response in both space, within the extended near-field, and through time, spanning a full production cycle. A comprehensive suite of process-related variables was measured on each occasion, which provides for assessments of resilience and relative assimilative capacity.

\section{MATERIALS AND METHODS}

\subsection{Site description and farm production}

This study was undertaken at a high-capacity salmon farm situated amidst semi-exposed rocky coastal island clusters in the Frøya region on the central west coast of Norway $\left(63.7^{\circ} \mathrm{N}\right.$; Fig. 1A,B). Wind and wave exposure is relatively high, as the surrounding low-lying islands offer little protection from wind and long-period southerly swells can propagate up the channels near the farm. The seabed around the farm comprised mixed substrates, with a complex bathymetry due to the many large rocky-reef structures separated by areas with soft sediments. Average current speeds (measured $4 \mathrm{~m}$ above the seabed) were affected by seasonal conditions (wind and swell) varying between 3 and $8 \mathrm{~cm} \mathrm{~s}^{-1}$, with maximum speeds regularly exceeding $25 \mathrm{~cm} \mathrm{~s}^{-1}$. The predominant current direction and net transportation is to the NNE during the flooding tide, with shorter periods of tidal reversal when currents flowed in a southerly direction. The primary study transect was oriented in accordance with the prevailing currents (Fig. 1C) over a relatively flat area with homogenous sand at 31-40 m water depth.

The study farm had been operated in single-yearclass production (single cohort grown through to harvest) for $15 \mathrm{yr}$ spanning 9 sequential production cycles. During the survey period, the farm comprised $14 \times 60 \mathrm{~m}$ diameter circular cages spread over ca. 11 ha of seabed (Fig. 1), which produced a total of ca. $9000 \mathrm{t}$ of fish. There are ca. 50 other operational farms in the wider region, many with comparable levels of production, the closest of which is $2.5 \mathrm{~km}$ to the north. Juvenile Atlantic salmon were introduced to the cages in May 2015 and harvested between May and June 2016. Harvest occurred early and at a smaller fish size than usual due to a disease outbreak, which may have also affected appetite and therefore feed use during the late stages. Feed use and associated waste discharge increased rapidly during the first 7 mo of the grow-out period, with 2 peaks on either side of the winter months (October-February). Average daily feed use at peak production just prior to harvesting was $35 \mathrm{t}$ (Fig. 2). The farms are managed on a single-cohort basis and a fallow period of between 5 and $7 \mathrm{mo}$ is implemented after each harvest.

\subsection{Sampling design}

Four sampling periods were designated a priori to coincide with: (1) when the fish were first introduced, after a 7 mo fallow period (August 2015 = 'early production'), (2) mid-production cycle (February $2016=$ 'mid-production'), (3) at peak production/pre-harvest (May 2016 = 'pre-harvest') and (4) 7 mo after the last fish were harvested (January 2017 = 'post-fallow') (Fig. 2). The early harvesting meant that approx. onethird of the cages were recently emptied at the time of the 'pre-harvest' survey.

Sampling stations were established at 2 besidecage locations at $0 \mathrm{~m}$ (labeled $0 \mathrm{~m}-\mathrm{A}$ and $0 \mathrm{~m}-\mathrm{B}$ ), and at 50,100,200, 400 and $600 \mathrm{~m}$ northward from the edge of the northernmost cage (Fig. 1C), as well as at 3 more distant 'reference' locations with similar substrates and depths $(1100,1200$ and $4000 \mathrm{~m})$. The distances used to denote the stations pertain to the distance to the nearest farm. The $1200 \mathrm{~m}$ station was situated $\sim 2100 \mathrm{~m} \mathrm{NE}$ of the main study farm but $1200 \mathrm{~m}$ WSW of an adjacent farm operating at similar production levels (Fig. 1). The $1100 \mathrm{~m}$ station was positioned NW of the main study farm still in the direction of the main currents, and the $4000 \mathrm{~m}$ station was more geographically and hydrodynamically removed from the main study area.

Depositional flux rates, multiple benthic environmental variables and benthic respiration were measured at each station during each sampling event. The only exception to this was during the early production survey, when the 0m-B, $1100 \mathrm{~m}$ and $4000 \mathrm{~m}$ stations were not sampled. These stations were added to the sampling array from the second mid-production survey. Additionally, it was not possible to obtain depositional flux measurements from the 50 and $100 \mathrm{~m}$ 


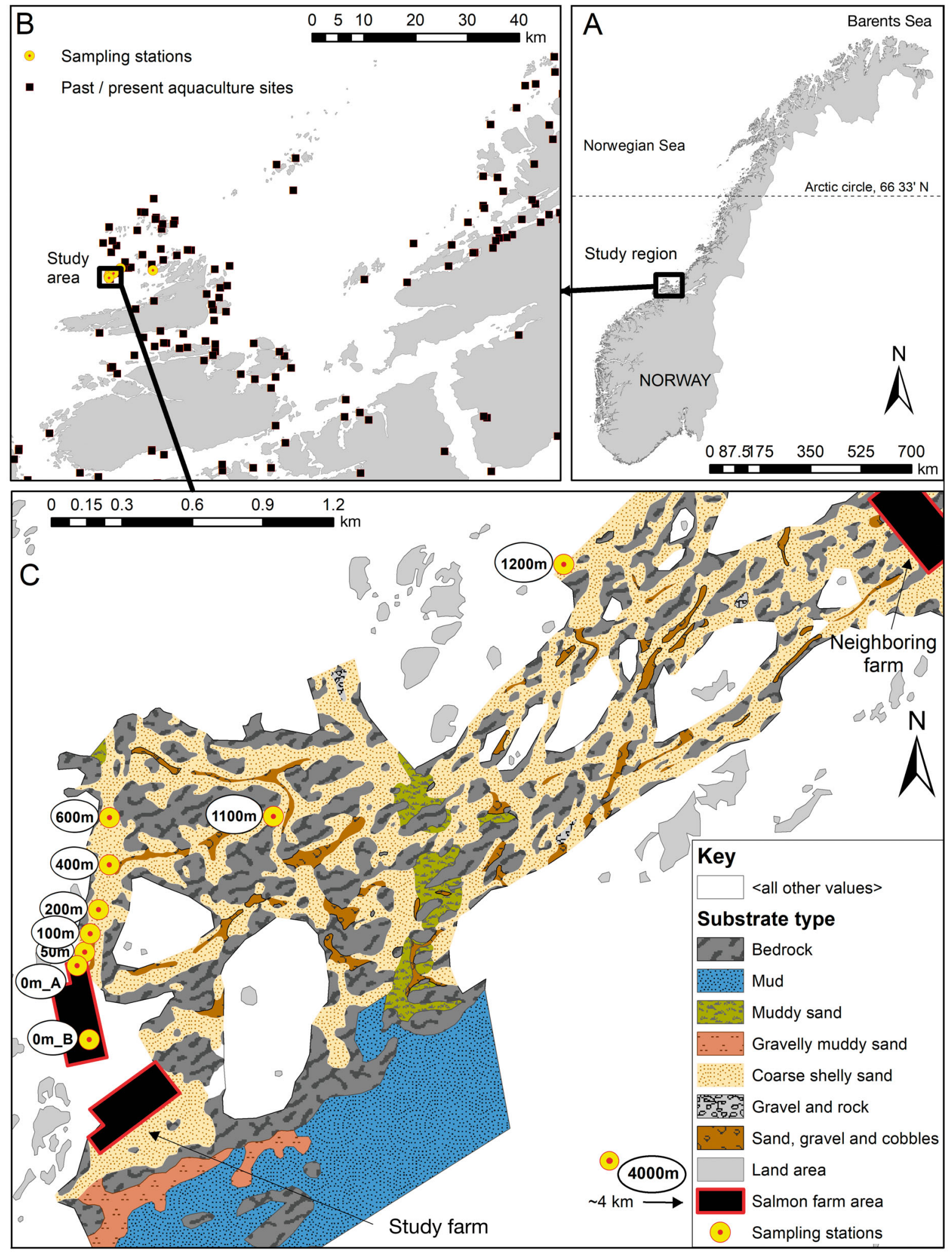

Fig. 1. (A) Location of the Frøya region on the west coast of Norway. (B) Study farm location within the Frøya Island network and locations of past/present salmon farms. (C) Location of the farm in relation to the mixed-substrate seabed (modified from Plassen et al. 2014) and indicating the position of the main transect and the 1100, 1200 and $4000 \mathrm{~m}$ sampling stations (station distances pertain to distances from the nearest farm) 
Fig. 2. Timeline of monthly feed use, total waste particulates discharged (assuming $25.6 \%$ as feces and $6.4 \%$ as waste feed) and carbon discharged $(38 \%$ in feces and $50 \%$ in waste feed; Woodcock et al. 2018) at the study farm in relation to the 4 specified survey periods: early production, mid-production, pre-harvest and post-fallow

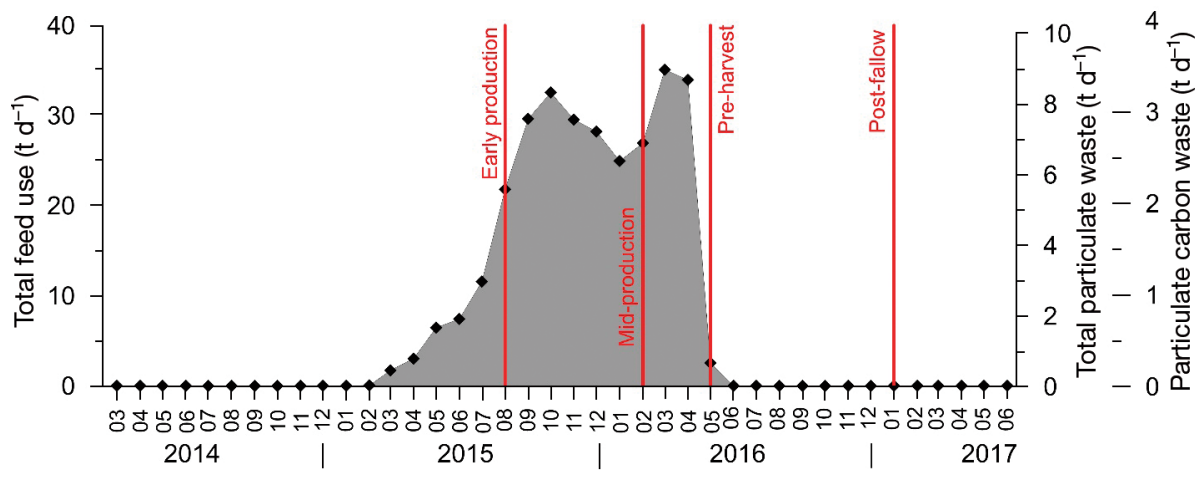

stations during the peak-production survey due to commercial boat traffic for harvesting and other access issues.

\subsubsection{Depositional flux measurements}

Deposition of suspended particulate matter was measured by deploying sediment traps at each station for a period of 8-14 d immediately prior to conducting the benthic sampling. Each mooring supported 2 frames, each holding duplicate sediment traps (inner diameter: $10 \mathrm{~cm}$, aspect ratio: 6, distance between cylinders: $90 \mathrm{~cm}$ ), with 1 frame $2.5 \mathrm{~m}$ above the bottom (mAB) and the other $15 \mathrm{mAB}$ (mid-water). Before deployment, all collecting cylinders were filled with clean seawater taken from the deployment site and $500 \mathrm{ml}$ saltwater ( $45 \%$ ) with ca. $4 \%$ buffered formalin added at the bottom of the cylinders as a preservative. After retrieval, the sediment traps were left to settle for $6-12 \mathrm{~h}$ before the top $70-80 \%$ of the water was carefully decanted off and the remaining sample (<2 l) transferred to a sample container and retained for subsequent analysis.

In the laboratory, the volume of the sample was recorded before the contents were homogenized (by vigorous shaking) and a representative 11 sub-sample was taken. The 11 sub-sample was then further subsampled with a $50 \mathrm{ml}$ Bird pipette after again homogenizing the contents. Three sub-samples from each collection cylinder were filtered through precombusted and weighed filters ( $47 \mathrm{~mm}$ Whatman GF/F). Two filters were for analysis of total particulate matter (TPM) and particulate organic matter (POM) after rinsing with $50 \mathrm{ml}$ of ammonium formate to remove salts and preservative. The third filter for stable isotope $\left(\delta^{13} \mathrm{C}\right.$ and $\delta^{15} \mathrm{~N}$ ) analysis was rinsed with $50 \mathrm{ml}$ of filtered seawater. Conspicuous organisms (e.g. copepods) were removed from the filters manually using a pair of forceps.

The dry weight of TPM on the filters was determined gravimetrically after the material was dried at $105^{\circ} \mathrm{C}$ for $24 \mathrm{~h}$. POM on the filters was determined as the weight loss after ignition at $450^{\circ} \mathrm{C}$ for $6 \mathrm{~h}$. Stable isotope analysis was conducted on $7 \mathrm{~mm}$ diameter circles stamped out of dried filters using a stainlesssteel core punch rinsed with $70 \%$ ethanol between samples. The filter subsamples were packed into tin capsules with sample weight dependent on farm production cycle and distance to nearest farm. For peak production, farm locations required one $7 \mathrm{~mm}$ diameter subsample, while reference locations required 2-3 such subsamples.

Carbonate was removed from dried sediment samples using a modification of the method described by Komada et al. (2008), and $0.1 \mathrm{~g}$ of sediment was weighed out into a glass vial and 5 drops of $\mathrm{HCl}$ were added. Samples were allowed to effervesce for $5 \mathrm{~min}$ at room temperature and were then placed in a drying oven at $50^{\circ} \mathrm{C}$ overnight. This process was repeated until effervescence was no longer observed in the majority of samples. For $0.1 \mathrm{~g}$ of sediment, approx. $10 \mathrm{aci}-$ dification cycles and a total of $2.5 \mathrm{ml} \mathrm{HCl}$ were required to remove carbonates. Samples were then stored in the oven to keep them dry before 40-50 mg of each sample were weighed out into tin capsules. All samples were analyzed by the University of California, Davis, Stable Isotope Facility for $\mathrm{C}$ and $\mathrm{N}, \delta^{15} \mathrm{~N}$ and $\delta^{13} \mathrm{C}$ using a PDZ Europa 20-20 isotope ratio mass spectrometer (Sercon). Samples were run against reference materials (bovine liver: $\delta^{13} \mathrm{C}=21.69, \delta^{15} \mathrm{~N}=$ 7.72; glutamic acid: $\delta^{13} \mathrm{C}=16.65, \% \mathrm{C}=40.81, \delta^{15} \mathrm{~N}=$ $-6.8, \% \mathrm{~N}=9.52$; enriched alanine: $\delta^{15} \mathrm{~N}=41.13$ ).

\subsubsection{Benthic sampling and taxonomy}

Triplicate sediment samples were collected from each station using a large, heavily weighted $0.1 \mathrm{~m}^{2}$ van Veen grab, which ensured adequate penetration into the sediment. Each successful grab was then sub-sampled for sediment geochemistry and macrofauna. For macrofauna (and respiration), a $10 \mathrm{~cm}$ 
diameter, 10-15 cm deep core was carefully removed without losing the interstitial waters, and a large bung was placed in the bottom end. Sediment cores were first used in respiration experiments (see Section 2.3.1) and then sieved through a $1 \mathrm{~mm}$ mesh. The material retained on the mesh was preserved with buffered $4 \%$ formalin and later analyzed for macrofauna. A full taxonomic investigation was conducted, whereby all fauna were picked out, counted and identified to the lowest possible taxonomic level. The organic and inorganic carbon content of the sediment was determined by drying the sediment at $40^{\circ} \mathrm{C}$ for $48 \mathrm{~h}$ followed by combustion at $450^{\circ} \mathrm{C}$ for 2 $\mathrm{h}$. Total number of species $(\mathrm{S})$, total abundance $(\mathrm{N})$ and Shannon-Wiener diversity index $\left(H^{\prime}\right.$, base e) were calculated for each sample.

Extensive video surveys were conducted of the seabed around the farm, along the study transect and at the reference sites during the pre-harvest period using a boat-mounted HD video with external lighting. This enabled a visual qualitative assessment of the benthic conditions based on expert judgment, which served as a visual reference for the measured variables.

\subsection{Benthic flux experiments}

\subsubsection{Benthic respiration: natural-core mesocosms}

In the laboratory, the sediment cores were placed in a tank containing seawater (ambient surface water temperature). The water level of the tank was below the top rim of the sediment cores and was maintained at a constant level via an overflow. Each sediment core was individually supplied with seawater through $0.5 \mathrm{~cm}$ diameter silicone tubing at a rate of approximately $200 \mathrm{ml} \mathrm{min}^{-1}$ from a submersible pump in a flow-through system (used water goes to waste) to maintain independence between sediment cores. Fluxes of total carbon dioxide $\left(\mathrm{TCO}_{21}\right)$, ammonium $\left(\mathrm{NH}_{4}\right)$ and oxygen $\left(\mathrm{O}_{2}\right)$ were determined on the sediment cores after $24-36 \mathrm{~h}$ of acclimatization. After taking initial water samples from the headspace in each sediment core, gas-tight lids equipped with a micro-pump (VBESTLIFE, $0.9 \mathrm{~W}$, submersible) for circulation were fitted. Sediment cores from the farming and reference locations were incubated for $1.5-3 \mathrm{~h}$ and $3-8 \mathrm{~h}$, respectively, depending on respiratory activity, before final water samples were collected. $\mathrm{TCO}_{2}$ samples were preserved with $\mathrm{HgCl}_{2}$ (volume ratio 9:1), stored $\operatorname{cool}\left(5^{\circ} \mathrm{C}\right)$ and analyzed by flow injection analysis (Hall \& Aller 1992) within $20 \mathrm{~d}$ of sample collection. Samples for $\mathrm{NH}_{4}$ were stored frozen $\left(-20^{\circ} \mathrm{C}\right)$ prior to undergoing colorimetric analysis as described by Kerouel \& Aminot (1997). The $\mathrm{O}_{2}$ concentration change during incubations was determined with a FIBOX $\mathrm{O}_{2}$ micro-optode (PreSens). The $\mathrm{TCO}_{2}$ results obtained from the post-fallowing survey were determined to be erroneous due to an analytical fault in that run. Therefore, $\mathrm{TCO}_{2}$ efflux for the post-fallow survey were estimated based on the $\mathrm{TCO}_{2}$ efflux from the jar incubations using the relationship between the results obtained from the previous 2 surveys (i.e. respiration efflux $=$ $2.44 \times$ jar incubation efflux $-0.834, R^{2}=0.834$ ).

\subsubsection{Total microbial organic carbon oxidation: jar experiments}

Bulk sediment samples were used for jar experiments as described by Kristensen \& Hansen (1995) and Valdemarsen et al. (2012), where mineralization rates in anoxic sediment were determined from the temporal change of $\mathrm{TCO}_{2}, \mathrm{NH}_{4}$ and $\mathrm{SO}_{4}$ in pore-water. Sediment from 2 depth layers ('shallow' $=0-3 \mathrm{~cm}_{i}$ 'deep' = $3-5 \mathrm{~cm}$ ) in undisturbed areas of the grab was homogenized and transferred to $20 \mathrm{ml}$ glass vials ('jars;' $\mathrm{n}=12$ ). Any air bubbles were removed and the jars were closed with screw caps and incubated head-down in anoxic sediment in the dark at constant temperature roughly corresponding to the average in situ temperature $\left(8^{\circ} \mathrm{C}\right)$. Pore-water was extracted from duplicate jars at $3 \mathrm{~d}$ intervals until no more jars remained. Jars were placed head-up in centrifuge tubes and centrifuged $(10 \mathrm{~min}$ at $1957 \times g)$. Pore-water was then sampled from the jar headspace, GF/C filtered and analyzed for $\mathrm{TCO}_{2}$ and $\mathrm{NH}_{4}$ as described above. The volumespecific reaction rates $\left(\mathrm{nmol} \mathrm{cm} \mathrm{cm}^{-3} \mathrm{~d}^{-1}\right)$ in individual depth layers were calculated from the slope of a plot of concentration vs. time and corrected for sediment porosity (Valdemarsen \& Kristensen 2005). The jar rates from the 2 depth layers were then depth integrated $(0-5 \mathrm{~cm})$ to provide an estimate of area-specific production rates of $\mathrm{CO}_{2}$ and $\mathrm{NH}_{4}$.

\subsection{Carbon accounting}

The organic carbon flux from the farm was compared to the organic carbon mineralization and accumulation in the surrounding benthic environment by converting all relevant rates to the same units of $\mathrm{gC}$ $\mathrm{m}^{-2} \mathrm{~d}^{-1}$. The organic carbon flux to the benthic environment was derived from the depositional flux data 

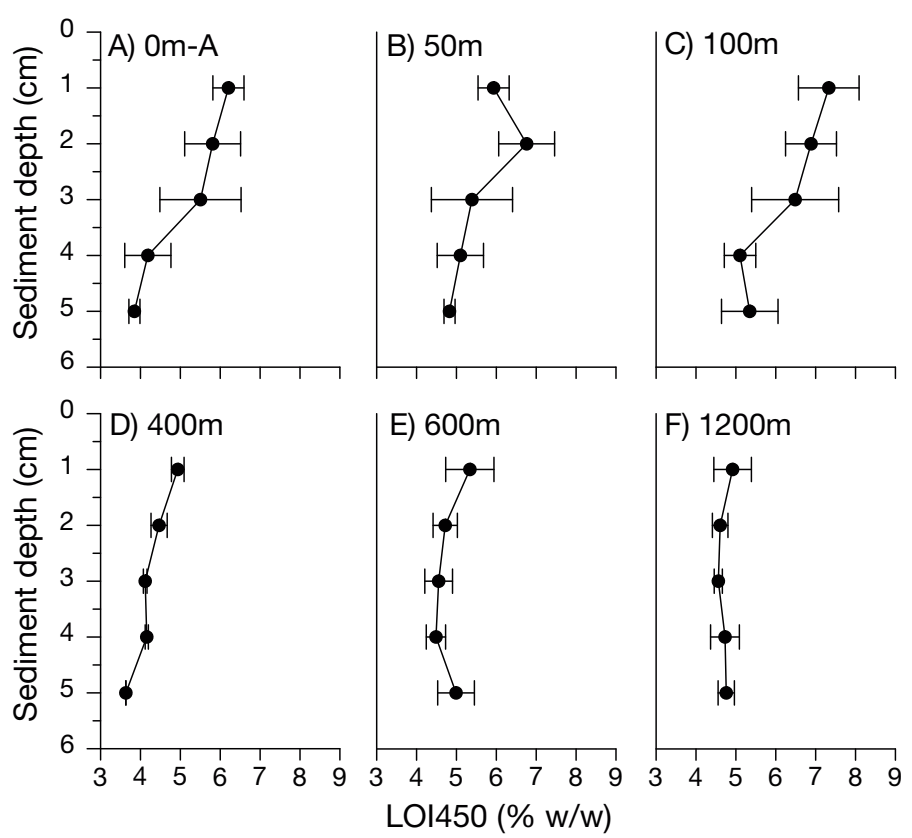

Fig. 3. Organic content (determined as the weight loss after ignition at $450^{\circ} \mathrm{C}$, LOI450) of sediment with depth $(1 \mathrm{~cm}$ bins to $5 \mathrm{~cm}$ ) and distance to nearest farm, from 0 to $1200 \mathrm{~m}$ during the pre-harvest survey. Error bars represent $\pm 1 \mathrm{SE}$ by multiplying TPM by the particulate organic carbon (POC) content. Benthic consumption (C) was estimated from the measured parameters based on the previously established general relationship for benthic fauna (Crisp 1984, Brey 2001):

$$
\mathrm{C}=\mathrm{E}+\mathrm{P}+\mathrm{R}
$$

where: $\mathrm{E}=$ excretion $\left(\mathrm{E}_{\mathrm{x}}\right.$, predominantly ammonia, carbon-free $)+$ egestion $\left(\mathrm{E}_{\mathrm{S}}\right), \mathrm{P}=$ production = somatic production $\left(\mathrm{P}_{\mathrm{S}}\right)+$ gonad production $\left(\mathrm{P}_{\mathrm{g}}\right)$, and $\mathrm{R}=$ respiration. For this purpose, R was the sum of macrofaunal (fR) and total microbial carbon oxidation $(\mathrm{mO})$ compartments. Benthic accumulation or burial (B), which is extraneous to biological consumption, was assessed as the accumulation of carbon directly in the sediments. Organic matter incorporation depth was assessed from depth-stratified core samples (Fig. 3). Hence, the overall carbon budget utilized here is given as follows:

$$
\text { Total carbon utilization }=\mathrm{B}+\mathrm{P}_{\mathrm{s}}+\mathrm{mO}+\mathrm{fR}
$$

Definitions for, and descriptions of, all compartments and how they were calculated are provided in Table 1.

Table 1. Definitions and methods used to convert accumulation and consumption compartments into standard carbon flux

\begin{tabular}{|c|c|}
\hline Compartment & Description \\
\hline Burial (B) & $\begin{array}{l}\text { Rate of change in organic carbon content of } \mathrm{CaCO}_{3} \text {-free defaunated sediments was based on } \\
\text { differences between subsequent samplings for each station. Change implies net accumulation or } \\
\text { remineralization (Sampou \& Oviatt 1991), given by: \% TOC } \times \text { sediment mass }\left(\mathrm{g} \mathrm{m}^{-2}\right)=\text { TOC in } \\
\text { sediment }\left(\mathrm{gC} \mathrm{m} \mathrm{m}^{-2} \text { ). TOC }=0.43 \times \mathrm{TOM} \text { (given by LOI450) as per Luczak et al. }(1997) \text {. Sediment mass }\right. \\
\text { standardized to } 1 \mathrm{~g} \text { of carbon-free sediment per } \mathrm{cm}^{2} \text { to account for the effects of density and porosity } \\
\text { on actual carbon amount per unit volume (Sampou \& Oviatt } 1991) \text {. Hence, effective depth varied } \\
\text { according to porosity. } 1 \mathrm{~g} \text { was chosen for these sediments because the depth analysis of sediment } \\
\text { penetration from the pre-harvest study indicated that carbon accumulation occurred down to } \\
\text { approximately } 3 \mathrm{~cm} \text { depth (see Fig. 3). The dry, carbon-free mass of sediment was } 0.36 \pm 0.05 \mathrm{~g} \mathrm{~cm}^{3} \\
\text { (average across sites } \pm 95 \% \mathrm{CI}) \text {; as such, } 1 \mathrm{~g} \text { of carbon-free sediment represents an active sediment } \\
\text { accumulation depth of approximately } 3 \mathrm{~cm}(2.9 \pm 0.6) \text { beneath a } 1 \mathrm{~cm}^{2} \text { area. Thus }\left(\mathrm{TOC}_{\mathrm{tn}}-\mathrm{TOC}_{\mathrm{tn}-1)}\right) \\
\text { days }=\text { burial rate }\left(\mathrm{gC} \mathrm{m}^{-2} \mathrm{~d}^{-1}\right) \text {. }\end{array}$ \\
\hline $\begin{array}{l}\text { Somatic produc- } \\
\text { tion }\left(\mathrm{P}_{\mathrm{s}}\right)\end{array}$ & 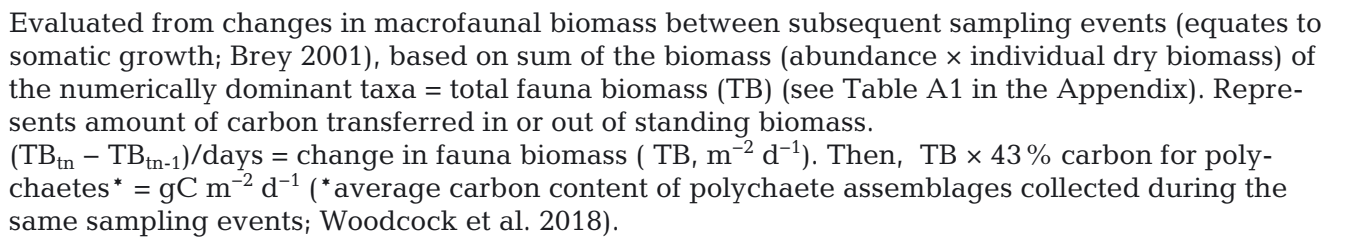 \\
\hline Respiration (R) & $\begin{array}{l}\text { Based on measured total carbon }\left(\mathrm{TCO}_{2}\right) \text { efflux from sediments. Represents level of respiratory } \\
\text { activity (including microbial activity) and associated carbon emissions from sediments. Assessed } \\
\text { here by assuming } 1 \mathrm{M} \text { carbon: } 1 \mathrm{M} \mathrm{TCO}_{2} \text {, converted to } \mathrm{gC} \mathrm{m}^{-2} \mathrm{~d}^{-1} \text {. }\end{array}$ \\
\hline $\begin{array}{l}\text { Total microbial } \\
\text { oxidation }(\mathrm{mO})\end{array}$ & $\begin{array}{l}\text { Total microbial organic carbon oxidation was determined as for } \mathrm{R} \text {, using the depth-integrated } \mathrm{TCO}_{2} \\
\text { fluxes obtained from the jar experiments. }\end{array}$ \\
\hline $\begin{array}{l}\text { Macrofauna } \\
\text { respiration (fR) }\end{array}$ & $\begin{array}{l}\text { Macrofauna respiration is determined by } \mathrm{R}-\mathrm{mO} \text { and therefore assumes that any excess } \mathrm{CO}_{2} \text { efflux } \\
\text { evident after subtracting microbial } \mathrm{CO}_{2} \text { efflux is due to macrofauna. }\end{array}$ \\
\hline
\end{tabular}
units. TOC: total organic carbon, TOM: total organic matter, LOI450: weight loss after ignition at $450^{\circ} \mathrm{C}$, tn: sampling period 

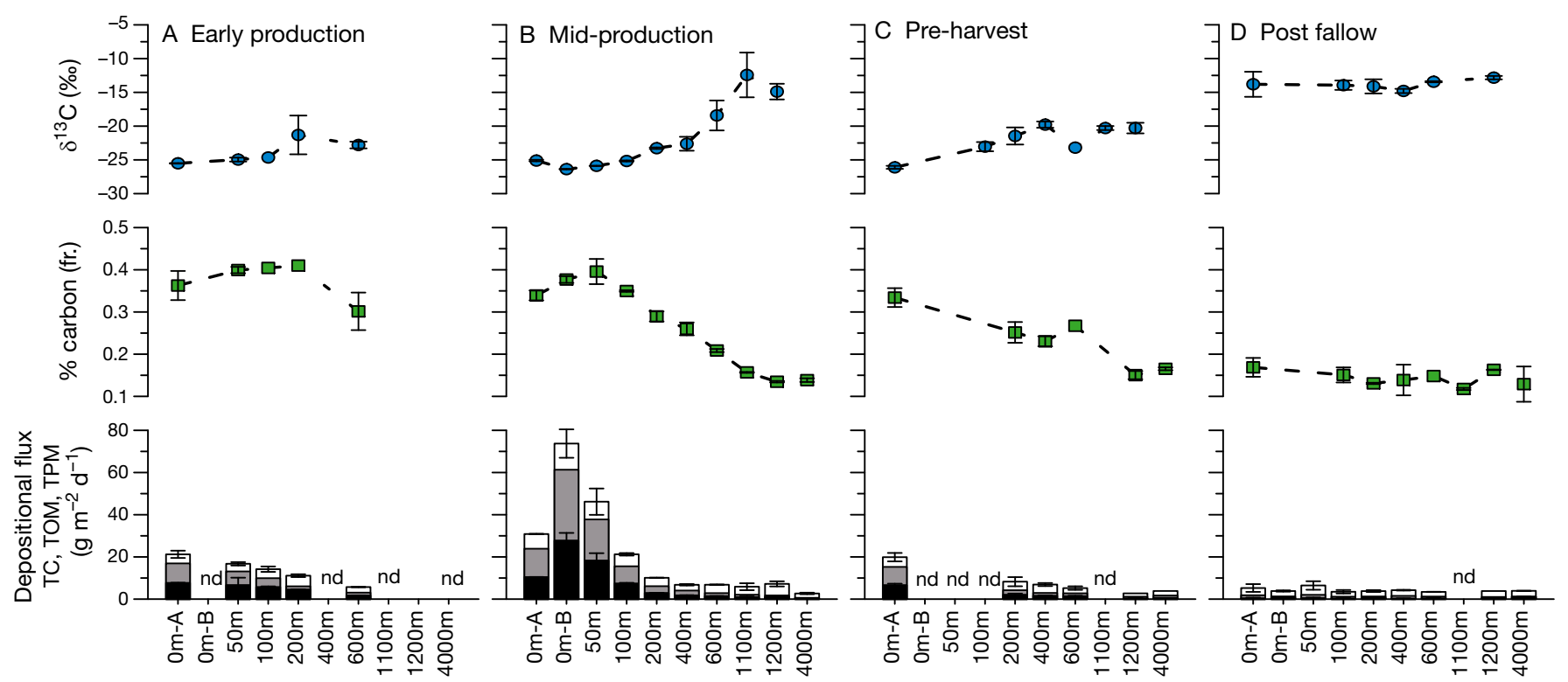

Fig. 4. Depositional fluxes during the 4 survey periods. Top 2 rows of plots: $\delta^{13} \mathrm{C}$ and \% carbon composition of particles (fraction) near-bottom (2.5 m above bottom [mAB]). Bottom row: rate of depositional flux measured by total particulate matter (TPM, top of white bars), total organic matter (TOM, top of grey bars) and total carbon (TC, black bars) for $2.5 \mathrm{mAB}$. Error bars represent $\pm 1 \mathrm{SE}_{;}$nd: no data

\section{RESULTS}

\subsection{Depositional fluxes}

Depositional fluxes of TPM, total organic matter (TOM) and total organic carbon (TOC) were already elevated out to $\sim 200 \mathrm{~m}$ from the farm ca. $5 \mathrm{mo}$ after the juvenile fish were introduced ('early production', Fig. 4A). TPM flux rate near the seabed $(2.5 \mathrm{mAB})$ was $21.1 \mathrm{~g} \mathrm{~m}^{-2} \mathrm{~d}^{-1}$ alongside the cages $(0 \mathrm{~m})$, and decreased to $16.7 \mathrm{~g} \mathrm{~m}^{-2} \mathrm{~d}^{-1}$ at $50 \mathrm{~m}$ distance and $4.3 \mathrm{~g}$ $\mathrm{m}^{-2} \mathrm{~d}^{-1}$ at $1100 \mathrm{~m}$ distance. The carbon content of TPM was generally higher $(36-40 \%)$ closer to the farm than further away (25-30\%), and $\delta^{13} \mathrm{C}$ was consistently low at all stations (Fig. 4A).

During the mid-production survey, depositional fluxes close to the cages had increased 3-4-fold compared to the initial survey (Fig. 4B). Near-bottom TPM fluxes peaked at $73.3 \mathrm{~g} \mathrm{~m}^{-2} \mathrm{~d}^{-1}\left(28 \mathrm{gC} \mathrm{m}^{-2}\right.$ $\mathrm{d}^{-1}$ ) at $0 \mathrm{~m}-\mathrm{B}$ and decreased rapidly out to $400 \mathrm{~m}$. Stations at 400 through $1200 \mathrm{~m}$ were elevated $\left(5.9-7.2 \mathrm{~g} \mathrm{~m}^{-2} \mathrm{~d}^{-1}\right)$ relative to the more distant station $\left(4000 \mathrm{~m}, 2.7 \pm 0.4 \mathrm{~g} \mathrm{~m}^{-2} \mathrm{~d}^{-1}\right)$. Both $\% \mathrm{C}$ and $\delta^{13} \mathrm{C}$ also showed clear trends with distance; the former decreased from a peak of $35-39 \% \mathrm{C}$ at 0 and $50 \mathrm{~m}$ to $13.2 \% \mathrm{C}$ at $1200 \mathrm{~m}$, while $\delta^{13} \mathrm{C}$ showed a clear inverse trend. The gradient evident in the midwater depositional flux values closely mirrored the near-bottom fluxes, only slightly reduced (peaking at $0 \mathrm{~m}-\mathrm{B}$ at $23.6 \mathrm{~g} \mathrm{~m}^{-2} \mathrm{~d}^{-1}$ ).
Depositional fluxes during the pre-harvest survey were lower than during mid-production, presumably due to some of the cages having recently been harvested. The $0 \mathrm{~m}-\mathrm{A}$ ( 2.5 and $15 \mathrm{mAB}$ ) and $0 \mathrm{~m}-\mathrm{B}$ were noticeably reduced compared to the previous midproduction survey. Deposition at mid-production was still clearly elevated $2.5 \mathrm{mAB}$ between 200 and $600 \mathrm{~m}$ $\left(5.2-8.2 \mathrm{~g} \mathrm{~m}^{-2} \mathrm{~d}^{-1}\right)$ relative to 1100 and $4000 \mathrm{~m}$ $\left(2.7-3.8 \mathrm{~g} \mathrm{~m}^{-2} \mathrm{~d}^{-1}\right)$. The POC content of deposited TPM remained elevated (compared to previous reference values) out to $600 \mathrm{~m}$, but decreased markedly at the 2 most distant stations. Changes in $\delta^{13} \mathrm{C}$ with distance were less pronounced than the previous survey. Unfortunately, no data were obtained from the 50 and $100 \mathrm{~m}$ stations (which we were unable to sample during this survey), or the bottom traps at $0 \mathrm{~m}-\mathrm{B}$, which were lost during retrieval.

Seven months after harvest, the depositional flux was expectedly low and uniform across all stations, ranging from $3.4-6.4 \mathrm{~g} \mathrm{~m}^{-2} \mathrm{~d}^{-1}$. Carbon content and $\delta^{13} \mathrm{C}$ were low, approximating reference values, and showed no clear trend with respect to proximity to farm.

\subsection{Sediment geochemistry}

The sediment along the transect was relatively uniform in composition, being hard-packed and noncohesive with an average grain size that classified it 


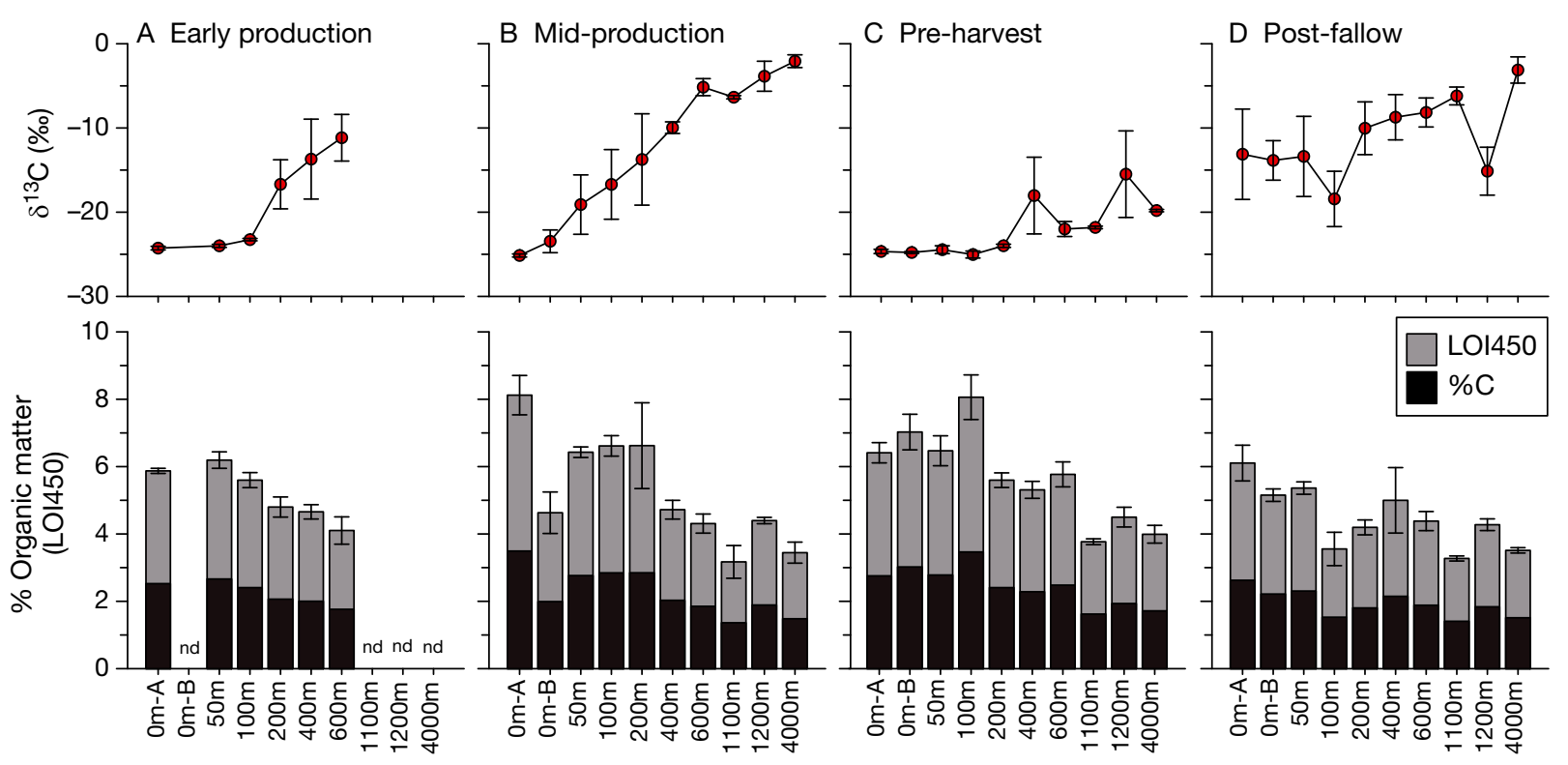

Fig. 5. $\delta^{13} \mathrm{C}$ in sediments and sediment organic matter (determined as the weight loss after ignition at $450^{\circ} \mathrm{C}, \mathrm{LOI} 450$ ) and $\%$ carbon of sediments. Error bars represent $\pm 1 \mathrm{SE} ; \mathrm{nd}$ : no data

as medium to coarse sand (average diameter $0.52 \mathrm{~mm}$, transect range [station average]: $0.31-0.82 \mathrm{~mm}$ ). Average sediment density and porosity along the transect were 1.5 (range: 1.2-1.6) and 59\% (range: 39-68\%), respectively, indicative of unconsolidated sandy sediments with a significant irregularly-shaped component (i.e. shell material) (McLachlan \& Turner 1994).

Sediment organic content (determined as the weight loss after ignition at $450^{\circ} \mathrm{C}$, LOI450) was typically $5-10 \%$ of dry weight, with values at the 2 most distant stations between 3.1 and $3.5 \% \mathrm{w} / \mathrm{w}$ (Fig. 5). The highest organic content $(8.1 \% \mathrm{w} / \mathrm{w})$ was recorded at 0m-A during mid-production and at the $100 \mathrm{~m}$ station during the pre-harvest survey, with elevated values also evident at 50 and $0 \mathrm{~m}$ stations and to a lesser extent at 200-600 m stations. Sediment organic content was also elevated during the mid-production survey at $0 \mathrm{~m}-\mathrm{A}$ and $50-200 \mathrm{~m}$ stations, when values (range $6.4-8.1 \% \mathrm{w} / \mathrm{w}$ ) were approximately twice as high as at the most distant stations.

Sediment $\delta^{13} \mathrm{C}$ showed clear trends with respect to proximity to the farm (Fig. 5). In the early production survey, $\delta^{13} \mathrm{C}$ was $-24 \%$ at $0 \mathrm{~m}-\mathrm{A}$ and $50 \mathrm{~m}$ and increased progressively with distance to -11 at the $600 \mathrm{~m}$ station. At mid-production, $\delta^{13} \mathrm{C}$ was -25 at $0 \mathrm{~m}-\mathrm{A}$ and increased with distance to values of between -2 and -4 at 1200 and $4000 \mathrm{~m}$, indicating that terrestrial carbon content increased significantly with proximity to the cage. The trend in the pre-harvest sediments was not so evident, with most stations, aside from 400 and $1100 \mathrm{~m}$, having low $\delta^{13} \mathrm{C}$ values.
Post-fallow, a distance gradient was still evident; however, the minimum $\delta^{13} \mathrm{C}(-18)$ was considerably lower than during early- and mid-production and occurred further down the transect, at the $100 \mathrm{~m}$ station.

\subsection{Macrofauna composition}

S and $H^{\prime}$ at the furthest (reference) stations (1100$4000 \mathrm{~m}$ ) ranged from 16-22 taxa core $^{-1}$ and 2.1-2.6, respectively (Fig. 6). Total abundances beyond $1000 \mathrm{~m}$ from the farm ranged from 1700-12 700 ind. $\mathrm{m}^{-2}$ over the course of the 4 surveys. At the first, early production survey (Fig. 6), both $\mathrm{S}$ and $H^{\prime}$ were consistently suppressed out to $200 \mathrm{~m}$, relative to the outer stations. In the mid-production and pre-harvest surveys, $\mathrm{S}$ and $H^{\prime}$ were suppressed (ranging from 6-12 taxa and 0.8-1.5 $H^{\prime}$ ) to a similar degree out to $600 \mathrm{~m}$ from the cages. The most affected station was 0m-B during the mid-production survey, with 5.6 taxa and $0.9 H^{\prime}$.

During early production, total abundance (Fig. 6) was clearly elevated $0-600 \mathrm{~m}$ from the cages relative to the most distant (reference) stations, with approx. 84000 ind. $\mathrm{m}^{-2}$ at $0 \mathrm{~m}$, tapering to $18000 \mathrm{~m}^{-2}$ at $400 \mathrm{~m}$. However, 3 mo later, at mid-production, abundances were substantially higher, peaking at $0 \mathrm{~m}-\mathrm{A}$ with 598000 ind. $\mathrm{m}^{-2}$ and reducing to 101000 ind. $\mathrm{m}^{-2}$ at $600 \mathrm{~m}$. At the $0 \mathrm{~m}$ stations, Capitella sp. comprised the vast majority by abundance (69-83\%), whereas between 50 and $600 \mathrm{~m}$ distance, capitellids 

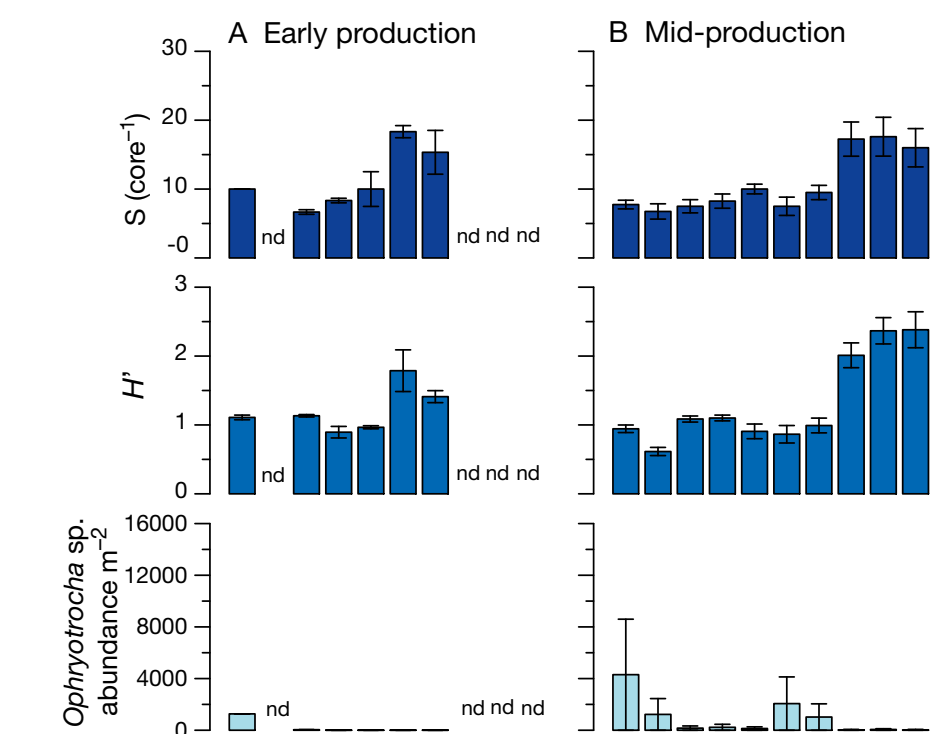

C Pre-harvest

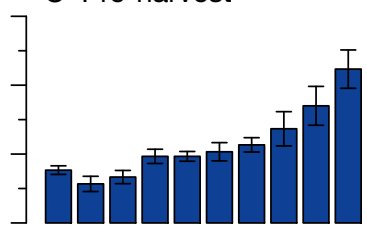

D Post fallow
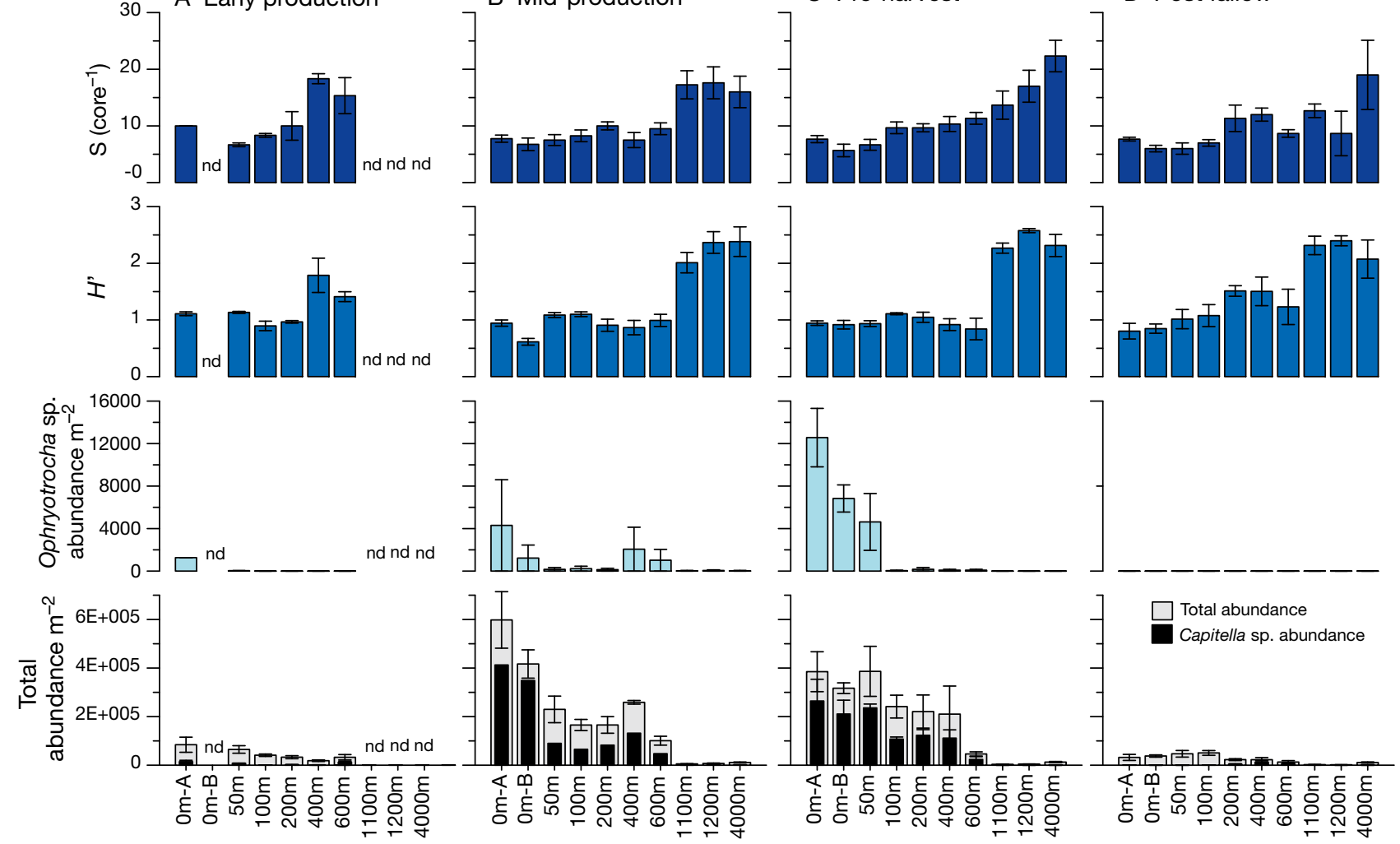

Fig. 6. Average macrofauna count data statistics during the 4 survey periods, showing number of taxa (S), Shannon diversity $\left(H^{\prime}\right)$ Ophryotrocha sp. abundance and total abundance (including Capitella spp. abundance) for each sampling station (labeled according to distance to nearest farm) during each survey. Error bars represent $\pm 1 \mathrm{SE}$; nd: no data

comprised approximately $40-50 \%$ of the macrofauna. Total abundances during the pre-harvest survey were comparable to the mid-production survey. At midproduction, macrofaunal densities were still clearly elevated out to $600 \mathrm{~m}$, but the difference between the densities at $0 \mathrm{~m}$ and the outer transect stations was not as pronounced, with 0 and $50 \mathrm{~m}$ stations being more comparable (310 000-380 000 ind. $\mathrm{m}^{-2}$ ) to the 50 to $400 \mathrm{~m}$ stations (210 000 and 240000 ind. $\mathrm{m}^{-2}$ ). During the pre-harvest survey, Ophryotrocha sp. were most abundant at 0m-A (12 500 ind. $\mathrm{m}^{-2}$ ) followed by $0 \mathrm{~m}-\mathrm{B}$ and then $50 \mathrm{~m}$, but were only present in very low densities at distances $>50 \mathrm{~m}$. After the short fallow period, total densities were greatly reduced and indicative of early production densities. The capitellid population was virtually absent.

\subsection{Benthic flux experiments}

\subsubsection{Benthic respiration: natural-core mesocosms}

Respiration experiments were not conducted during the initial, early production survey. During the mid-production survey, $\mathrm{TCO}_{2}$ effluxes were strongly elevated along the transect, generally increasing with proximity to the cages, although peaking at $50 \mathrm{~m}\left(359 \pm 100 \mathrm{mmol} \mathrm{m}^{-2} \mathrm{~d}^{-1}\right.$, Fig. 7). By comparison, $\mathrm{TCO}_{2}$ effluxes at the most distant stations (1100$4000 \mathrm{~m}$ ) were between 0 and $13.9 \mathrm{mmol} \mathrm{m}^{-2} \mathrm{~d}^{-1}$. $\mathrm{TCO}_{2}$ effluxes during the pre-harvest survey were comparable, but notably elevated further out along the transect, at the 100 and $200 \mathrm{~m}$ stations (130 and $230 \mathrm{mmol} \mathrm{m}^{-2} \mathrm{~d}^{-1}$, respectively). Overall, $\mathrm{TCO}_{2}$ effluxes were approximately twice as high as $\mathrm{O}_{2}$ fluxes during both surveys. Estimated $\mathrm{TCO}_{2}$ fluxes during the postfallow survey were relatively low, ranging between 5 and $50 \mathrm{mmol} \mathrm{m}^{-2} \mathrm{~d}^{-1}$.

Trends in $\mathrm{NH}_{4}$ efflux mirrored $\mathrm{O}_{2}$ uptake, except for during the mid-production survey when $\mathrm{NH}_{4}$ efflux at 0m-B and $100 \mathrm{~m}$ was seemingly suppressed relative to $\mathrm{O}_{2}$ uptake. During the first survey, $\mathrm{O}_{2}$ uptake peaked at $0 \mathrm{~m}-\mathrm{B}$ at $140 \mathrm{mmol} \mathrm{m} \mathrm{d}^{-1}$, compared to rates of between 7.9 and $12.1 \mathrm{mmol} \mathrm{m}^{-2} \mathrm{~d}^{-1}$ at the most distance reference stations, representing a 10-fold increase due to farm wastes. Notably, $\mathrm{O}_{2}$ uptake was significantly elevated at $600 \mathrm{~m}$ relative to the more distant stations and increased gradually toward $200 \mathrm{~m}$, 


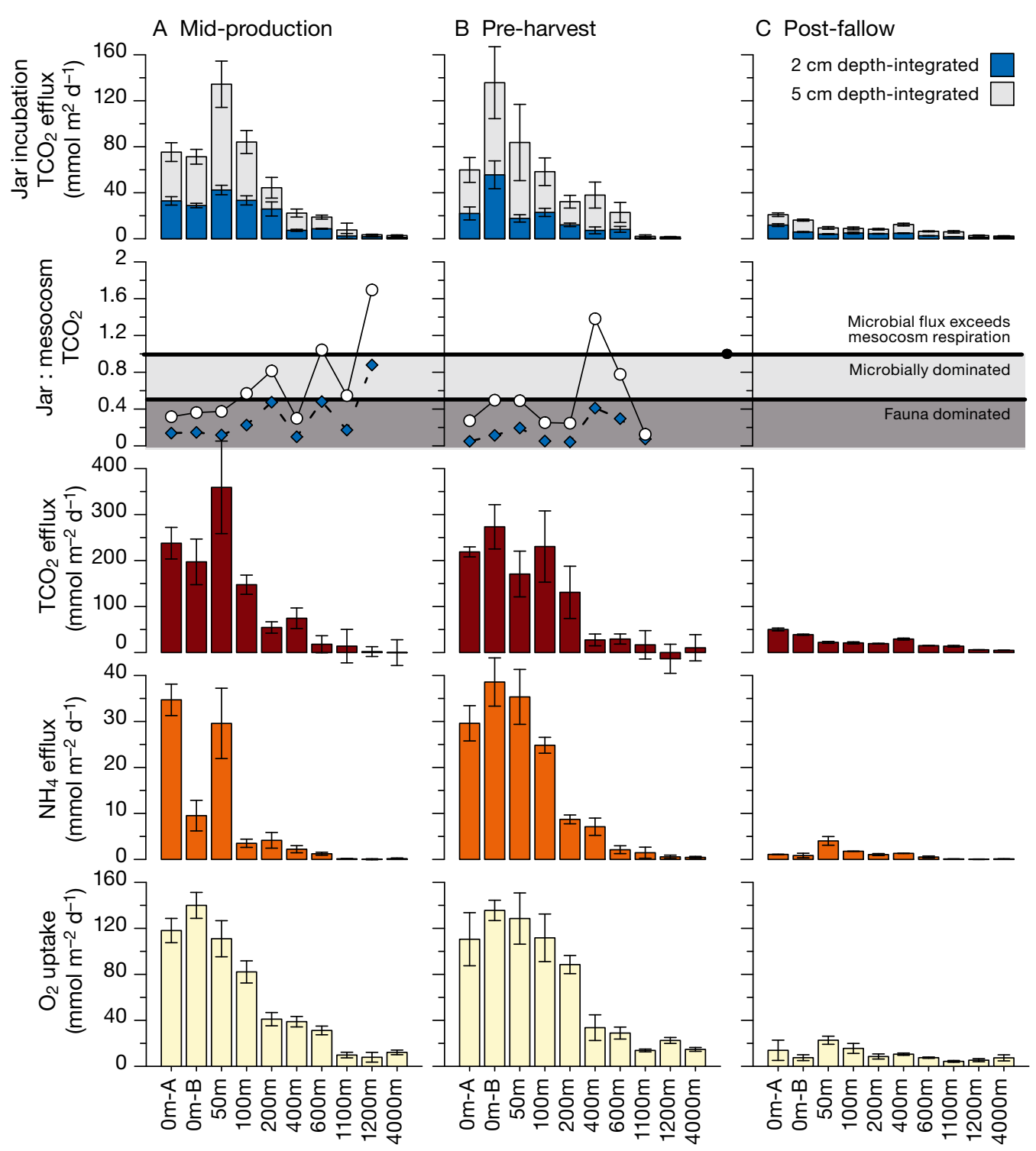

Fig. 7. Benthic respiration. Top row: average total carbon dioxide $\left(\mathrm{TCO}_{2}\right)$ efflux from top $2 \mathrm{~cm}$ of sediment and top $5 \mathrm{~cm}$ of sediment from jar incubations of decaudated sediments. Second row: ratio between $\mathrm{TCO}_{2}$ efflux from jar incubations (microbial) and respiration cores (ignoring ratios that include near- 0 or negative values). Bottom 3 rows: $\mathrm{TCO}_{2}$ and $\mathrm{NH}_{4}$ effluxes and $\mathrm{O}_{2}$ uptake from natural respiration cores for each sampling station (labeled according to distance to nearest farm) during each of the last 3 surveys. Note: $\mathrm{TCO}_{2}$ efflux for the post-fallow survey was estimated based on the $\mathrm{TCO}_{2}$ production from the jar incubations (see Section 2). Error bars represent $\pm 1 \mathrm{SE}$

with larger sequential increases from $100 \mathrm{~m} \ll 50 \mathrm{~m}$ $\ll 0 \mathrm{~m}$. The rates and spatial trends during the preharvest survey were similar, with the main differences being generally increased $\mathrm{NH}_{4}$ eflux and $\mathrm{O}_{2}$ uptake away from the cages, from 50 through $200 \mathrm{~m}$. Additionally, $\mathrm{O}_{2}$ uptake was approximately 3 times as high at $1100 \mathrm{~m}$ relative to 1200 and $4000 \mathrm{~m}$.

After the fallow period, $\mathrm{NH}_{4}$ efflux and $\mathrm{O}_{2}$ uptake were greatly reduced, with all stations recording near-background levels. The only exceptions were 50 and $100 \mathrm{~m}$, which were slightly elevated relative to the more distant stations.

\subsubsection{Total microbial oxidation of organic carbon}

$\mathrm{TCO}_{2}$ production rates from the jar incubations of defaunated sediments closely mirrored $\mathrm{TCO}_{2}$ and $\mathrm{O}_{2}$ fluxes from the natural core mesocosms during the mid-production and pre-harvest surveys (Fig. 7). A clear gradient was evident from the 0 and $50 \mathrm{~m}$ stations out to $1200 \mathrm{~m}$. $\mathrm{TCO}_{2}$ efflux from sediments peaked at the $50 \mathrm{~m}$ station during mid-production $\left(134 \mathrm{mmol} \mathrm{m}{ }^{-2} \mathrm{~d}^{-1}\right)$ and at 0m-B $\left(135 \mathrm{mmol} \mathrm{m} \mathrm{d}^{-2} \mathrm{~d}^{-1}\right)$ during the pre-harvest survey. In both cases, the $5 \mathrm{~cm}$ sediment depth fluxes were $31-35 \%$ of the corre- 
sponding mesocosm fluxes. Microbial respiration was more elevated further out along the transect during the pre-harvest survey than during mid-production. A clear gradient with respect to distance from farms was still evident post-fallow, although levels were much lower $\left(2.3-20.9 \mathrm{mmol} \mathrm{m} \mathrm{m}^{-2} \mathrm{~d}^{-1}\right.$ ). During the whole study, $35-40 \%$ of total depth integrated $\mathrm{TCO}_{2}$ flux occurred in the top $2 \mathrm{~cm}$.

During the mid-production and pre-harvest surveys, $\mathrm{TCO}_{2}$ efflux was more than twice as high as total microbial $\mathrm{TCO}_{2}$ production based on jar experiments, indicating a high influence of faunal respiration on $\mathrm{TCO}_{2}$ fluxes out to $100-200 \mathrm{~m}$ distance from the nearest farm (Fig. 7, second row). Further away, microbial respiration often comprised $>50 \%$ of the total $\mathrm{TCO}_{2}$ production, and on 2 occasions (at 4000 and $400 \mathrm{~m}$ ), microbial respiration exceeded fluxes produced by a natural core in mesocosm experiments.

\subsection{Carbon inputs and utilization}

For this part of the analysis, the flux of carbon $(\mathrm{gC}$ $\mathrm{m}^{-2} \mathrm{~d}^{-1}$ ) into, or out of, each of the compartments: deposition, sediment burial (B), somatic growth/production $\left(\mathrm{P}_{\mathrm{s}}\right)$, macrofauna respiration (fR) and microbial and chemical respiration $(\mathrm{mO})$ were calculated as described in Table 1. Between the early production and mid-production surveys, organic carbon burial beneath the cages (0m-A and 0m-B) occurred at an average rate of $0.96 \mathrm{gC} \mathrm{m}^{-2} \mathrm{~d}^{-1}$. Between midproduction and pre-harvest, this rate reduced to approximately $0.25 \mathrm{gC} \mathrm{m}^{-2} \mathrm{~d}^{-1}$, after which the flux was slightly negative (i.e. an overall reduction in carbon content in sediments) suggesting release to the water column or decomposition (Fig. 8A1). At 50 and $100 \mathrm{~m}$ stations, average carbon burial was low during the first 2 periods, but significantly elevated between

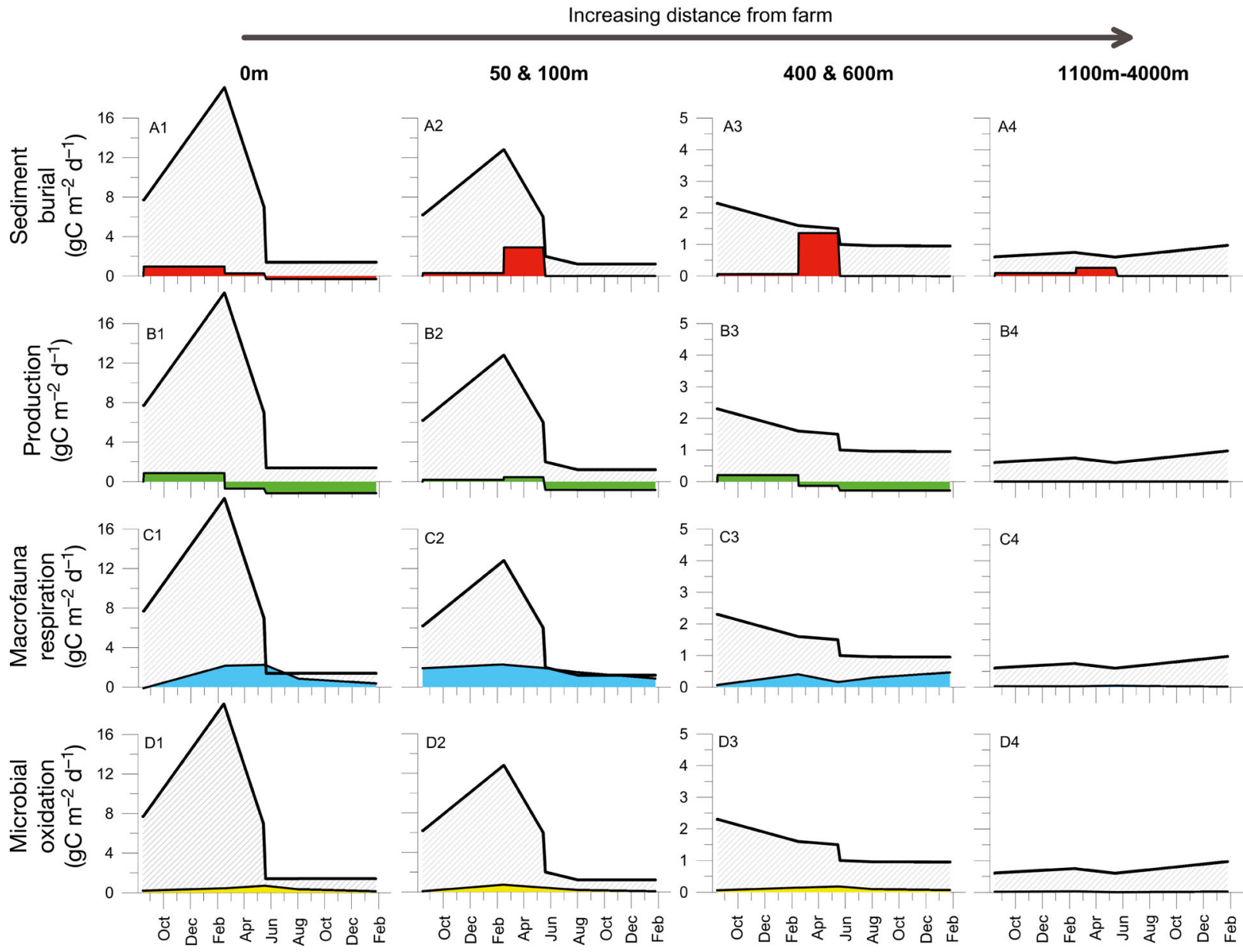

Fig. 8. Carbon utilization in relation to influx for compartments: sediment burial (red area), fauna production/somatic growth (green), macrofaunal respiration (blue) and total microbial oxidation (yellow) and 4 distances along the main transect: $0 \mathrm{~m}$ stations (A1-D1; stations 0m-A and 0m-B averaged), 50 and $100 \mathrm{~m}$ stations (A2-D2; averaged), 400 and $600 \mathrm{~m}$ stations (A3-D3; averaged), 1100-4000 m stations (A4-D4; averaged). Solid black line and hatched area on each plot indicate depositional flux $\left(\mathrm{gC} \mathrm{m}^{-2} \mathrm{~d}^{-1}\right)$. Note the $y$-axis scale change between 0 and 50-100 $\mathrm{m}$ and the more distant stations $(400-600$ and $1100-4000 \mathrm{~m})$ 
mid-production and pre-harvest, accumulating at a rate of $2.9 \mathrm{gC} \mathrm{m}^{-2} \mathrm{~d}^{-1}$ (Fig. 8A2). Further away (400-600 m), carbon burial was negligible during the first 2 periods; however, the notable increase in sediment carbon content at the pre-harvest survey indicated a significant burial event at a time-averaged rate of $1.4 \mathrm{gC} \mathrm{m}^{-2} \mathrm{~d}^{-1}$ (Fig. 8A3). Carbon burial during the mid-production to pre-harvest period was approximately equivalent to the flux measured $2.5 \mathrm{~m}$ above the seabed. A similar but much less pronounced trend was evident in the third period at the 1100-4000 m stations (Fig. 8A4), at which point the accumulation rate accounted for approximately half of the depositional flux.

Beneath the cages $(0 \mathrm{~m})$, somatic growth/production $\left(\mathrm{P}_{\mathrm{s}}\right.$, reflecting change in estimated macrofauna biomass between survey periods) was positive $\left(0.8 \mathrm{gC} \mathrm{m}^{-2} \mathrm{~d}^{-1}\right)$ between early- and mid-production (Fig. 8B1). Standing biomass was estimated to be less at the pre-harvest survey, indicating a net loss $\left(-0.7 \mathrm{gC} \mathrm{m}^{-2} \mathrm{~d}^{-1}\right)$ in carbon from the benthos, and net loss increased between pre-harvest and post-fallow $\left(-1.2 \mathrm{gC} \mathrm{m}^{-2} \mathrm{~d}^{-1}\right)$ as the previously highly abundant opportunistic taxa disappeared from the benthos. At the $50-100 \mathrm{~m}$ stations, weak positive somatic growth was observed between mid-production and preharvest, but negative growth was observed between then and the final survey (Fig. 8B2). Similar patterns were evident at $400-600 \mathrm{~m}$ stations but on a much smaller and negligible scale.

Organic carbon loss from the sediment due to macrofauna respiratory processes peaked beneath the cages during the mid-production and pre-harvest surveys at 2.1 and $2.3 \mathrm{gC} \mathrm{m}^{-2} \mathrm{~d}^{-1}$, respectively (Fig. 8C1). Interestingly, the higher values at preharvest occurred after the fauna biomass peak at mid-production. A similar response was observed at the 50-100 m stations, except that the peak was observed at mid-production rather than at preharvest (Fig. 8C2). Similar temporal responses were observed further away at both the $400-600 \mathrm{~m}$ stations and the 1100-4000 m stations, only on a much smaller scale, peaking at 0.4 and $0.05 \mathrm{gC} \mathrm{m}^{-2} \mathrm{~d}^{-1}$, respectively (Fig. 8C3,C4).

Carbon release due principally to chemical and microbial processes (depth-integrated to $5 \mathrm{~cm}$ ) followed a very similar pattern to that described for the fauna due to the correlated $\mathrm{TCO}_{2}$ fluxes from the mesocosms and jar experiments. The defaunated sediments accounted for a small but consistent amount of the total flux at the $0,50-100$ and the $400-600 \mathrm{~m}$ distances. Microbial respiration peaked during preharvest at 0.7 and $0.2 \mathrm{gC} \mathrm{m}^{-2} \mathrm{~d}^{-1}$ at 0 and $400-600 \mathrm{~m}$, respectively. Microbial respiration at the distant stations (1100-4000 m) was negligible by comparison.

\section{DISCUSSION}

Salmon farms operating in relatively shallow, dispersive coastal ecosystems with sandy sediments can produce comparatively large benthic environmental footprints. Clear changes to the chemical and biological variables spatially and temporally consistent with farm-induced enrichment were evident out to $600 \mathrm{~m}$ from the cages. The horizontal extent of this footprint is $4-10$ times as large as what has typically been assessed for fish farms located in more conventional low-flow sites of similar depth (ca. 40-150 m distance: Brooks et al. 2002, Hargrave 2003, Giles 2008, Keeley et al. 2013a). While Kutti et al. (2007b) identified a larger footprint than is described here, that was from a single-mooring farm situated within a deep $(230 \mathrm{~m})$ fjord, where the ability of the cages to move with the prevailing currents and the greater depth permitted greater dispersal and spread of waste particles (Cromey et al. 2002). Assessments from other dispersive sites situated in comparable depths of 30-50 m revealed effects out to 300-400 m from the cages (Keeley et al. 2013a,b). Traces of farm waste have been recorded at greater distances; for example, changes in fatty acid (White et al. 2017) and stable isotope (Sarà 2007, Woodcock et al. 2018) composition have been identified 500 and $1000 \mathrm{~m}$ away, respectively. However, these 'tracer' studies did not make clear links to corresponding ecological effects per se, and are therefore best interpreted as defining a zone of possible influence. Our study revealed both elevated depositional fluxes and clear ecological changes in the seabed $600 \mathrm{~m}$ away from the farm, and the outer extent of the effects boundary was assessed to be somewhere between 600 and $1100 \mathrm{~m}$ away.

Comprehension of this spatial scale is important for the design of benthic monitoring programs and for farm positioning, particularly with regard to avoiding overlapping effects and maintaining appropriate distances from any potentially sensitive habitats. For this study, an assumption was made a priori that locations beyond $1 \mathrm{~km}$ from any farm should be indicative of natural conditions and therefore should be appropriate for use as 'reference' stations. In retrospect, a distance of 1.5-2 km may have been more appropriate, as our results suggest that both the 1100 and $1200 \mathrm{~m}$ stations were probably periodically exposed to low levels of farm waste. With that in mind, it is in- 
teresting to note that in this instance, finding suitable reference locations was challenged by substrate and depth availability, but also by the proximity to neighboring farms. Benthic footprints from farms situated in dynamic water bodies are, however, unlikely to be uniformly distributed around the farm as the stronger tide- or wave-driven currents elongate the footprint in the prevailing directions of transportation (Keeley et al. 2013b, Broch et al. 2017). In this example, reasonably distinct channels existed between large rock reefs and islands, which presumably influenced the hydrodynamics and exaggerated the bilateral distortion of the footprint to some degree. The chosen transect was deliberately located in the primary 'down-current' direction where the spatial extent of effects was greatest. Particle transportation, and with that, benthic enrichment effects, in directions perpendicular to the main currents were presumably relatively constrained. Hence, site-specific factors are paramount when evaluating new sites. Conducting high-resolution bathymetric surveys and spatially explicit waste dispersal modeling is particularly important for predicting effects footprints at dispersive or bathymetrically complex sites.

Despite the strong benthic effects gradient that was observed, the seabed along the main study transect remained visibly unimpacted, which meant there was a clear disconnect between visual indicators and actual biological and geochemical status of the seabed. This clearly poses a problem for monitoring programs based on visual indicators such as bacterial mat coverage, presence of feces and feed pellets, sediment color and biological changes (e.g. Crawford et al. 2001, Wilson et al. 2009). Presence of hydrogen sulfide odor, which can also be used as an effects indicator, was also noticeably weak in near-farm sediments. At peak production, some fish feces were evident in small pockets immediately adjacent to the cages, but these aggregations were temporally variable (presumably due to periodic resuspension) and consistently absent $>50 \mathrm{~m}$ away from the farm. Likewise, the use of other indicators such as the depth of the redox discontinuity layer (O'Reilly et al. 2006) and acoustic backscatter (Wildish et al. 2004) are also likely to be limited in effectiveness as the sediments were not conventionally organically enriched and generally lacked grey/black discontinuity layers. The strong environmental gradient that was observed was best elucidated by the extraction and identification of the faunal community and the study of geochemical fluxes in undisturbed cores. In the absence of these parameters, it would be easy to wrongly assume that effects were negligible and the vast majority of waste is being exported. Visually-based assessments of dispersive sites are therefore prone to risk of returning a false negative.

An important finding from this study was the high level of responsiveness and therefore resilience observed in the geochemical and biological properties of the near-farm sediments. Over the course of the production cycle, the sediments went from being very minimally impacted at the start of the production cycle, to being highly geochemically active with an extremely prolific population of opportunistic worms 3 mo later. Seven months after final harvesting, the very high respiratory activity that was present during production had almost ceased and the opportunistic taxa had all but disappeared. Notably, there were no signs of incremental degradation or of organic accumulation in the sediments, suggesting sustainability in relation to the production cycles. While similarly rapid responses have been described for chemical remediation in sediments (Brooks et al. 2003), full recovery is normally expected to take several years mainly due to the biological component (Brooks et al. 2004, Borja et al. 2010, Keeley et al. 2014). In this case, it was notable that although total abundance, and in particular abundances of Capitella spp., quickly reverted to a normal range, macrofauna diversity and species richness remained suppressed at the conclusion of the fallow period, suggesting that rare and/or more sensitive species had not yet recolonized the sediments.

The seemingly anomalous relationship between very high fish production levels and the general benthic enrichment state was confirmed by the measured depositional flux rates which were strongly elevated (maximum of 20-27 $\mathrm{gC} \mathrm{m}^{-2} \mathrm{~d}^{-1}$ ) and at levels that would normally be associated with highly degraded conditions. By comparison, comparable fluxes (12$23 \mathrm{gC} \mathrm{m}^{-2} \mathrm{~d}^{-1}$ ) were measured at a low current site in the Norwegian fjords in conjunction with a severely impoverished benthic fauna and benthic malfunctioning (Valdemarsen et al. 2015). Even lower fluxes have been associated with the approximate threshold at which sediment becomes azoic $\left(2.5-4.8 \mathrm{gC} \mathrm{m}^{-2} \mathrm{~d}^{-1}\right.$; Findlay \& Watling 1997) and when persistent anoxia, gross pollution and very low macrofauna diversity can be expected (10 gC m${ }^{-2} \mathrm{~d}^{-1}$; Hargrave et al. 2008) at low flow sites. In another example, Keeley et al. (2013b) equated a depositional flux of $11.2 \mathrm{gC} \mathrm{m}^{-2} \mathrm{~d}^{-1}$ to highly enriched, but not yet anoxic or azoic, conditions for dispersive sites. Notably, that example was under sustained inputs with multi-year-class farming, and assuming it is applicable to other dispersive locations, the long-term sustainability of the current study 
site may have been partly a result of the single-yearclass fallowing strategy.

The process by which this resilience (as indicated by the capacity to recover quickly) was afforded can be attributed to the physical properties of the site, which culminated in a high assimilative capacity (defined here as the ability to cope with organic waste without resulting in unacceptable biological or geochemical conditions). In this case, the resilience was therefore explained by the extremely prolific opportunistic macrofauna assemblage, which was in turn supported by: (1) an unlimited food supply, (2) resuspension, not allowing the particles to settle long enough to consolidate and accumulate (e.g. depositional modeling [DEPOMOD] uses a consolidation time for organic particles of $4 \mathrm{~d}$; Cromey et al. 2002) and (3) essentially unlimited oxygen supply buffering against anoxia (Findlay \& Watling 1997, Keeley et al. 2013a). This was clearly evident in the responsiveness of the macrofaunal population and its relatively large contribution to the carbon utilization.

Another potentially important physical site characteristic influencing waste assimilation and resilience was the composition of the sediments. Sediment morphology has the potential to influence both the ecological suitability for the macrofauna and mineralization of organic matter more directly through microbial pathways. An unlimited oxygen supply to organically enriched sediments facilitates maximal rates of microbial mineralization, and minimizes accumulation of organic matter and potentially toxic by-products of microbial processes such as hydrogen sulfide (Valdemarsen et al. 2009, Martinez-Garcia et al. 2015). The extent to which this occurs is a function of pore-water residence time, which strongly influences the mineralization of organic matter and nutrient release to overlying waters (Santos et al. 2012). While traditional low-flow depositional sites tend to have cohesive non-permeable muds, the sandy, unconsolidated sediments here presumably had a relatively high 3-dimensional aspect that would promote solute distribution and transportation, and the establishment of geochemical reaction zones, which facilitates benthic production and decomposition (Huettel et al. 2014). Of the multiple physical factors that drive pore-water advection (Santos et al. 2012), the ones that were most likely to be relevant at this location were flow-induced advection, shear stresses and to a lesser degree, wave pumping and ripple migration (as some small wave-ripples were evident during some of the video surveys). All of these factors are a product of the hydrodynamics of a site, and hence grain size cannot sensibly be considered in isolation.
Despite being somewhat dwarfed by the macrofaunal component, the contribution to carbon utilization attributed to the microbes of between 0.5 and $0.7 \mathrm{gC}$ $\mathrm{m}^{-2} \mathrm{~d}^{-1}$ was still considered significant. High $\mathrm{TCO}_{2}$ effluxes relative to the $\mathrm{O}_{2}$ fluxes indicate the prevalence of anaerobic pathways during the peak production periods, which would have been partly facilitated by bacteria implicit in sulfate reduction (Hargrave et al. 2008, Valdemarsen et al. 2009). The composition of the microbial community may also be related to physical grain size which has been linked to microbial capacity, respiration and carbon turnover, as microbes preferentially grow on sandy substrates (Miller 1989). However, the links between microbial groups and ecosystem function in permeable sediments are not yet fully understood (Huettel et al. 2014). Additionally, in strongly organically enriched situations, the microbial flora associated with the organic waste is more likely to predominate over that of the natural substrates. It is also conceivable that the permeability of the sediments could eventually become compromised by the finer waste deposits close to the farm filling the interstitial spaces, thereby favoring biologically driven processes (e.g. bio-irrigation, detrital consumption by fauna) over the advection-related process mentioned above (Huettel et al. 2014). However, this was not apparent in the grain size or porosity statistics, which indicated no clear trend with proximity to farm.

Although highly responsive and remaining biologically functional, the benthic processes measured in this study accounted for between 30 and $100 \%$ of the organic waste that was emitted from the farm, dependent on space and time (Fig. 9). During the early and mid-stages of the farming period, approximately $30-40 \%$ of the carbon was being metabolized by the benthos in the immediate vicinity, leaving $60-70 \%$ unaccounted for and available to influence other parts of the environment. The most likely pathways for this extraneous waste are: (1) break-up, decomposition or assimilation in the water column, the scope for which is presumably exacerbated by turbulence and resuspension increasing time spent in the water column, (2) consumption or enhanced bio-irrigation by large benthic fauna (e.g. mobile epifauna such as sea cucumbers, and sparse infauna such as large bivalves or lugworms) that are not well enumerated by conventional benthic sampling, and/or (3) transported further away and deposited in a dilute form in far-field depositional areas. The scope for farfield effects from sedimentation and eutrophication are often acknowledged, but the subtle and intangible nature means assessments mostly draw on 


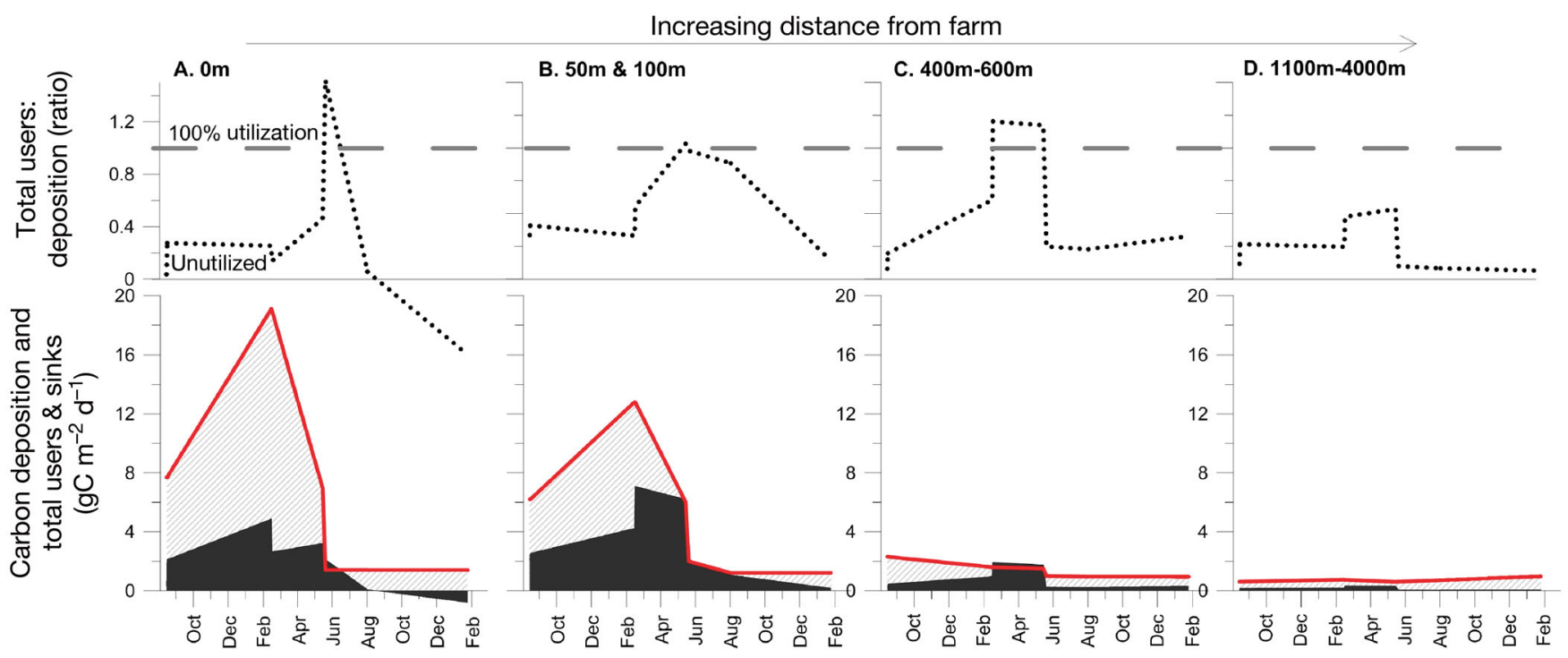

Fig. 9. Sum of total measured carbon consumption, use and accumulation (black area = burial + somatic growth + macrofaunal respiration + microbial oxidation) in relation to deposition flux (inputs, red line) through the production cycle at 4 distances along the main transect: $0 \mathrm{~m}$ stations (A1-A4; stations 0m-A and 0m-B averaged), 50 and $100 \mathrm{~m}$ stations (B1-B4; averaged), 400 and $600 \mathrm{~m}$ stations (C1-C4; averaged), 1100-4000 m stations (D1-D4; averaged)

predictive models and involve much speculation (Hargrave 2003). In one such modeling scenario, Bannister et al. (2016) predicted that approximately $25 \%$ of waste may fall $>500 \mathrm{~m}$ from the farm and $2.7 \%>2 \mathrm{~km}$ away. Although reasonably consistent with the bottom-up approach taken in this study, it is difficult to make direct comparisons, as that study was conducted in a deep fjord system.

Nevertheless, it is reasonable to conclude from the data provided here, that organic waste from highly productive dispersive sites has the potential to influence larger areas than previously perceived, i.e. it has far-field effects. As such, there is increased capacity to influence food webs and specific benthic fauna that are not traditionally monitored, some of which may be ecologically or commercially important. This finding is reinforced by a related study by Woodcock et al. (2018), who identified of traces of waste feed in 2 species of mobile epifauna up to $1 \mathrm{~km}$ from the same farm; one of these species was the commercially harvested brown crab Cancer pagurus. It would logically follow that the scope for far-field effects is greater in dispersive regions containing multiple farms with potentially overlapping footprints, where effects are most likely to manifest in naturally depositional areas in the vicinity. However, a critical unknown factor that will dictate the scope for such effects concerns the fate (and longevity) of particles in the water column, which warrants further investigation. Moreover, whether the influence from such mild enrichment is positive or negative is a matter of subjectivity, and is also likely to be very species-specific. In particular, the effects should also be considered in the context of integrated multi-trophic level aquaculture, whereby there can be benefits to other commercial valuable species (e.g. Troell et al. 2009).

The carbon accounting calculations in space and time also revealed an interesting burial event that occurred along the transect down-current from, but not directly beneath, the cages (Fig. 9). This burial event coincided with the late stages of production as well the spring/early summer period, when primary production is often elevated (Erga et al. 2017, Paulino et al. 2018). The event may therefore be partly a nat$\mathrm{ural} / \mathrm{seasonal}$ process, but the trends with respect to farm proximity and timing in relation the production cycle would suggest that it was principally a response to farm waste discharges. Curiously, at 400-600 $\mathrm{m}$ from the farm, the estimated consumption of organic waste by the benthos late in the production cycle actually exceeded the level of deposition flux. One plausible explanation is that there is often a lag of 1 to 3 mo between the deposition of POM and its mineralization and associated peaks in oxygen consumption rates (Hargrave 1978, Rudnick \& Oviatt 1986). Hence, most of the sediment incorporation likely occurred a few months after peak production, when water temperatures and biological activity were also higher. A further explanation may be that the flux measurements under-represented the flux at the sediment-water interface. The flux measurements here were from $2.5 \mathrm{~m}$ above the seabed, but 
subsequent video observations from the site at a similar time of year revealed elevated levels of particulate matter being transported on or just above the seabed that was not being sampled by the traps. Benthic boundary layer fluxes of particles are a known artifact of relationships between boundary shear stresses and the Rouse parameter and can result in significant near-bottom horizontal transportation of particles (Rouse 1940, Thomsen et al. 2002). The macrofaunal attrition that occurred in response to reducing and ceasing feed inputs may also have contributed to both the elevated nearbottom organic detritus and the observed accumulation events. Expiring fauna will either be mineralized and integrated into the sediment or released in particulate form and transported away by the currents. The absence of an accumulation event at the $0 \mathrm{~m}$ stations is difficult to explain, although it may be a function of accelerated currents beneath aquaculture structures (Turner et al. 2016), which would promote scouring and prevent particles from settling.

\section{CONCLUSION}

This study provides a comprehensive assessment of organic waste output and benthic functioning at a high-capacity farm situated in a relatively shallow, dispersive site in western Norway. The sandy benthic substrate proved resilient to artificially high levels of organic enrichment. The benthic fauna and biogeochemical exchanges between sediment and water responded dramatically to increased farm production and returned to pre-stocking state within 7 mo of the farm being harvested. The metabolic activity of macrofauna accounted for the majority of the measured benthic waste assimilation, and the ability to do so was ultimately attributed to the physical properties (i.e. hydrodynamics) of the site. Although assimilative during production, substantive fauna attrition at the end of the production cycle may also release carbon back to the system. Collectively, our results suggest that single-year-class sea cage farming at dispersive sites with routine fallowing appears to be sustainable (maintaining a functional benthos and exhibiting rapid partial recovery) with peak depositional fluxes on the order of $25 \mathrm{gC} \mathrm{m}^{-2} \mathrm{~d}^{-1}$. This finding is somewhat contrary to previous suggestions that site depth is a critical factor for waste dispersal and effects mitigation. Here, the under-pen depth was less than half of the total water column depth, suggesting that current speeds and sediment type can have an overriding influence.
The drawback to farming in dispersive environments is that the footprint is larger than for nondispersive locations, which means greater consideration must be given to farm positioning and proximity to valuable habitats and fisheries resources. There is also increased scope for minor ecological changes in the far-field, especially if there are multiple farms in the same water body. A recommended safe distance for the siting of uninfluenced reference stations is $2 \mathrm{~km}$ from the nearest farm. This study also emphasizes that absence of organic accumulation or any obvious visual evidence of effects does not necessarily equate to no impact; rather, pronounced ecological changes may be occurring but in a more aerobic and readily reversible manner. However, whilst the benthic condition returned to the previous prestocking state by the end of the fallowing period, macrofaunal diversity remained compromised. The long-term sustainability of farming a site can be evaluated by routinely monitoring the benthic condition at the end of the fallowing period and looking for degenerative trends between harvest cycles.

Acknowledgements. This study was supported by the Norwegian Research Council (Project number 228871) with additional in-kind support from SalMar ASA. We are grateful to field assistance provided by Pia Kupka Hansen, Siri Olsen, Marcos Fernández and Ragni Olssøn, and the boat and field support provided by the team at Åkeblå consulting.

\section{LITERATURE CITED}

Bannister RJ, Johnsen IA, Hansen PK, Kutti T, Asplin L (2016) Near- and far-field dispersal modelling of organic waste from Atlantic salmon aquaculture in fjord systems. ICES J Mar Sci 73:2408-2419

Belle SM, Nash CE (2008) Better management practices for net-pen aquaculture. In: Tucker CS, Hargreaves JA (eds) Environmental best management practices for aquaculture. John Wiley \& Sons, Oxford, p 261-330

Borja Á, Dauer D, Elliott M, Simenstad C (2010) Mediumand long-term recovery of estuarine and coastal ecosystems: patterns, rates and restoration effectiveness. Estuaries Coasts 33:1249-1260

*Bavo F, Grant J (2018) Modelling sediment assimilative capacity and organic carbon degradation efficiency at marine fish farms. Aquacult Environ Interact 10:309-328

*Brey T (2001) Population dynamics in benthic invertebrates. A virtual handbook. Version 01.2. Alfred Wegener Institute for Polar and Marine Research. www.thomas-brey. de/science/virtualhandbook

Broch OJ, Daae RL, Ellingsen IH, Nepstad R, Bendiksen EÅ, Reed JL, Senneset G (2017) Spatiotemporal dispersal and deposition of fish farm wastes: a model study from central Norway. Front Mar Sci 4:199

* Brooks KM, Mahnken CVW (2003) Interactions of Atlantic salmon in the Pacific northwest environment: II. Organic wastes. Fish Res 62:255-293 
Brooks KM, Mahnken C, Nash C (2002) Environmental effects associated with marine netpen waste with emphasis on salmon farming in the Pacific Northwest. In: Stickney RR, McVey J (eds) Responsible marine aquaculture. CABI, Wallingford, p 159-203

Brooks KM, Stierns AR, Mahnken CVW, Blackburn DB (2003) Chemical and biological remediation of the benthos near Atlantic salmon farms. Aquaculture 219:355-377

Brooks KM, Stierns AR, Backman C (2004) Seven year remediation study at the Carrie Bay Atlantic salmon (Salmo salar) farm in the Broughton Archipelago, British Columbia, Canada. Aquaculture 239:81-123

* Brown JH, Gillooly JF, Allen AP, Savage VM, West GB (2004) Toward a metabolic theory of ecology. Ecology 85: 1771-1789

Chamberlain J, Stucchi D (2007) Simulating the effects of parameter uncertainty on waste model predictions of marine finfish aquaculture. Aquaculture 272:296-311

Crawford CM, Mitchell IM, Macleod CK (2001) Video assessment of environmental impacts of salmon farms. ICES J Mar Sci 58:445-452

Crisp DJ (1984) Energy flow measurements. In: Eleftheriou A, Holme N (eds) Methods for the study of marine benthos, 2nd edn. Blackwell Scientific Publications, Oxford, p 284-372

Cromey CJ, Nickell TD, Black KD (2002) DEPOMOD - modelling the deposition and biological effects of waste solids from marine cage farms. Aquaculture 214:211-239

* Cromey CJ, Thetmeyer H, Lampadariou N, Black KD, Kogeler J, Karakassis I (2012) MERAMOD: predicting the depositional and benthic impact of aquaculture in the eastern Mediterranean Sea. Aquacult Environ Interact 2: $157-176$

Erga SR, Haugen SB, Bratbak G, Egge JK, Heldal M, Mork KA, Norland S (2017) Seasonal variations in C:N:Si:Ca:P: $\mathrm{Mg}: \mathrm{S}: \mathrm{K}: F e$ relationships of seston from Norwegian coastal water: impact of extreme offshore forcing during winterspring 2010. Mar Chem 196:1-12

Findlay RH, Watling L (1997) Prediction of benthic impact for salmon net-pens based on the balance of benthic oxygen supply and demand. Mar Ecol Prog Ser 155:147-157

Frid CLJ, Mercer TS (1989) Environmental monitoring of caged fish farming in macrotidal environments. Mar Pollut Bull 20:379-383

Giles H (2008) Using Bayesian networks to examine consistent trends in fish farm benthic impact studies. Aquaculture 274:181-195

Goldberg ED (1981) Use of the ocean for mans wastes. Symposium proceedings, June 1981. Convened by the Steering Committee on the engineering aspects of using the assimilative capacity of the oceans for the Marine Board, Assembly of Engineering, National Research Council. National Academy Press, Washington, DC

Gowen RJ, Bradbury NB (1987) The ecological impact of salmon farming in coastal waters: a review. Oceanogr Mar Biol Annu Rev 25:563-575

Hall POJ, Aller RC (1992) Rapid, small-volume, flow injection analysis for $\Sigma \mathrm{CO}_{2}$ and $\mathrm{NH}_{4}^{+}$in marine and freshwaters. Limnol Oceanogr 37:1113-1119

Hargrave BT (1978) Seasonal changes in oxygen uptake by settled particulate matter and sediments in a marine bay. J Fish Res Board Can 35:1621-1628

Hargrave BT (2002) A traffic light decision system for marine finfish aquaculture siting. Ocean Coast Manag 45: 215-235

Hargrave BT (2003) Far-field environmental effects of marine finfish aquaculture. A scientific review of the potential environmental effects of aquaculture in aquatic ecosystems. Fisheries and Oceans Canada, Ottawa

* Hargrave BT, Holmer M, Newcombe CP (2008) Towards a classification of organic enrichment in marine sediments based on biogeochemical indicators. Mar Pollut Bull 56: 810-824

Huettel M, Berg P, Kostka JE (2014) Benthic exchange and biogeochemical cycling in permeable sediments. Annu Rev Mar Sci 6:23-51

* Ibrekk HO, Kryvi H, Elvestad S (1993) Nationwide assessment of the suitability of the Norwegian coastal zone and rivers for aquaculture (LENKA). Coast Manag 21:53-73

Keeley NB, Forrest BM, Macleod CK (2013a) Novel observations of benthic enrichment in contrasting flow regimes with implications for marine farm monitoring and management. Mar Pollut Bull 66:105-116

Keeley NB, Cromey CJ, Goodwin EO, Gibbs MT, Macleod CM (2013b) Predictive depositional modelling (DEPOMOD) of the interactive effect of current flow and resuspension on ecological impacts beneath salmon farms. Aquacult Environ Interact 3:275-291

Keeley NB, Macleod CK, Hopkins GA, Forrest BM (2014) Spatial and temporal dynamics in macrobenthos during recovery from salmon farm induced organic enrichment: When is recovery complete? Mar Pollut Bull 80:250-262

Kerouel R, Aminot A (1997) Fluorometric determination of ammonia in sea and estuarine waters by direct segmented flow analysis. Mar Chem 57:265-275

*Komada T, Anderson MR, Dorfmeier CL (2008) Carbonate removal from coastal sediments for the determination of organic carbon and its isotopic signatures, $\delta^{13} \mathrm{C}$ and $\delta^{14} \mathrm{C}$ : comparison of fumigation and direct acidification by hydrochloric acid. Limnol Oceanogr Methods 6:254-262

Kristensen E, Hansen K (1995) Decay of plant detritus in organic-poor marine sediment: production rates and stoichiometry of dissolved $\mathrm{C}$ and $\mathrm{N}$ compounds. J Mar Res 53:675-702

Kutti T, Ervik A, Hansen PK (2007a) Effects of organic effluents from a salmon farm on a fjord system. I. Vertical export and dispersal processes. Aquaculture 262:367-381

Kutti T, Hansen PK, Ervik A, Høisæter T, Johannessen P (2007b) Effects of organic effluents from a salmon farm on a fjord system. II. Temporal and spatial patterns in infauna community composition. Aquaculture 262:355-366

KLaw BA, Hill PS, Milligan TG, Zions V (2016) Erodibility of aquaculture waste from different bottom substrates. Aquacult Environ Interact 8:575-584

Kisson D (2014) Risks to the Tasmanian abalone fishery from further expansion of the salmonid industry. Tasmanian Abalone Council Hobart, https://tasabalone.com.au/wpcontent/uploads/2016/11/Risks-to-the-Tasmanian-Aba lone-Fishery-from-further-expansion-of-the-SalmonidIndustry-October-2014.pdf

* Luczak C, Janquin MA, Kupka A (1997) Simple standard procedure for the routine determination of organic matter in marine sediment. Hydrobiologia 345:87-94

* Martinez-Garcia E, Carlsson M, Sanchez-Jerez P, SánchezLizaso JL, Sanz-Lazaro C, Holmer M (2015) Effect of sediment grain size and bioturbation on decomposition of organic matter from aquaculture. Biogeochemistry 125:133-148

Mayor DJ, Solan M (2011) Complex interactions mediate the effects of fish farming on benthic chemistry within a region of Scotland. Environ Res 111:635-642

* McLachlan A, Turner I (1994) The interstitial environment of sandy beaches. Mar Ecol 15:177-212

Merican ZO, Phillips MJ (1985) Solid waste production from 
rainbow trout (Salmo gairdneri Richardson) cage culture. Aquacult Res 16:55-69

Miller DC (1989) Abrasion effects on microbes in sandy sediments. Mar Ecol Prog Ser 55:73-82

MPI (Ministry for Primary Industries) (2013) Literature review of ecological effects of aquaculture. A collaboration between Ministry for Primary Industries, Cawthron Institute \& National Institute for Water and Atmospheric Research Ltd. Ministry for Primary Industries, Wellington

O'Reilly R, Kennedy R, Patterson A, Keegan BF (2006) Ground truthing sediment profile imagery with traditional benthic survey data along an established disturbance gradient. J Mar Syst 62:189-203

Papageorgiou N, Kalantzi I, Karakassis I (2010) Effects of fish farming on the biological and geochemical properties of muddy and sandy sediments in the Mediterranean Sea. Mar Environ Res 69:326-336

Paulino AI, Larsen A, Bratbak G, Evens D, Erga SR, Bye-Ingebrigtsen E, Egge JK (2018) Seasonal and annual variability in the phytoplankton community of the Raunefjord, west coast of Norway from 2001-2006. Mar Biol Res 14:421-435

Plassen L, Olsen H, Longva O (2014) Bunnsedimenter (kornstørrelse). Environmental Responses to Aquaculture (ERA). www.mareano.no/kart/mareano.html.

Rouse H (1940) Criteria for similarity in the transportation of sediment. Univ Iowa Stud Eng 20:33-49

Rudnick DT, Oviatt CA (1986) Seasonal lags between organic carbon deposition and mineralization in marine sediments. J Mar Res 44:815-837

Sampou P, Oviatt CA (1991) Seasonal patterns of sedimentary carbon and anaerobic respiration along a simulated eutrophication gradient. Mar Ecol Prog Ser 72:271-281

Santos IR, Eyre BD, Huettel M (2012) The driving forces of porewater and groundwater flow in permeable coastal sediments: a review. Estuar Coast Shelf Sci 98:1-15

Sarà G (2007) A meta-analysis on the ecological effects of aquaculture on the water column: dissolved nutrients. Mar Environ Res 63:390-408

Thomsen L, vanWeering T, Gust G (2002) Processes in the benthic boundary layer at the Iberian continental margin and their implication for carbon mineralization. Prog Oceanogr 52:315-329

Troell M, Joyce A, Chopin T, Neori A, Buschmann AH, Fang JG (2009) Ecological engineering in aquaculture - potential for integrated multi-trophic aquaculture (IMTA) in marine offshore systems. Aquaculture 297:1-9

Turner AA, Jeans TL, Reid, GK (2016) Experimental investigation of fish farm hydrodynamics on 1:15 scale model square aquaculture cages. J Offshore Mech Arct Eng 138:061201

Valdemarsen T, Kristensen E (2005) Diffusion scale dependent change in anaerobic carbon and nitrogen mineralization: true effect or experimental artifact? J Mar Res 63: 645-669

Valdemarsen T, Kristensen E, Holmer M (2009) Metabolic threshold and sulfide-buffering in diffusion controlled marine sediments impacted by continuous organic enrichment. Biogeochemistry 95:335-353

*Valdemarsen T, Bannister RJ, Hansen PK, Holmer M, Ervik A (2012) Biogeochemical malfunctioning in sediments beneath a deep-water fish farm. Environ Pollut 170:15-25

Valdemarsen T, Hansen PK, Ervik A, Bannister RJ (2015) Impact of deep-water fish farms on benthic macrofauna communities under different hydrodynamic conditions. Mar Pollut Bull 101:776-783

WWalters BB (2007) Competing use of marine space in a modernizing fishery: salmon farming meets lobster fishing on the Bay of Fundy. Can Geogr 51:139-159

Wang X, Olsen LM, Reitan KI, Olsen Y (2012) Discharge of nutrient wastes from salmon farms: environmental effects, and potential for integrated multi-trophic aquaculture. Aquacult Environ Interact 2:267-283

White CA, Nichols PD, Ross DJ, Dempster T (2017) Dispersal and assimilation of an aquaculture waste subsidy in a low productivity coastal environment. Mar Pollut Bull 120:309-321

*Wildish DJ, Hughes-Clarke JE, Pohle GW, Hargrave BT, Mayer LM (2004) Acoustic detection of organic enrichment in sediments at a salmon farm is confirmed by independent groundtruthing methods. Mar Ecol Prog Ser 267:99-105

Wilson A, Magill S, Black KD (2009) Review of environmental impact assessment and monitoring in salmon aquaculture. In: Environmental impact assessment and monitoring in aquaculture. FAO Fisheries and Aquaculture Tech Pap 527. FAO, Rome, p 455-535

*Woodcock SH, Strohmeier T, Strand Ø, Olsen SA, Bannister RJ (2018) Mobile epibenthic fauna consume organic waste from coastal fin-fish aquaculture. Mar Environ Res $137: 16-23$

\section{Appendix.}

Table A1. Numerically dominant fauna with proportion that each taxon comprised out of the total number of individuals (for the entire dataset), measured average individual biomass

\begin{tabular}{|lcc|}
\hline Taxon & $\begin{array}{c}\text { \% of total number } \\
\text { of individuals }\end{array}$ & $\begin{array}{c}\text { Average individual } \\
\text { biomass }(\mu \mathrm{g})\end{array}$ \\
\hline Capitella sp. & 57.8 & 1.23 \\
Nematoda & 25.0 & 0.06 \\
Oligochaeta & 11.5 & 0.24 \\
Ophryotrocha sp. & 1.1 & 1.83 \\
Dorvilleidae & 0.2 & 0.01 \\
Total & 96.1 & - \\
\hline
\end{tabular}

Editorial responsibility: Jonathan Grant, Halifax, Nova Scotia, Canada
Submitted: August 1, 2018; Accepted: January 29, 2019 Proofs received from author(s): April 17, 2019 